\title{
La responsabilidad del empleado público en España
}

\author{
Liability of public servants in Spain
}

Miguel León Acosta

Fecha correspondencia:

Recibido: 7 de octubre de 2019. Revisión: 8 de noviembre de 2019. Aceptado: 12 de noviembre de 2019.

Forma de citar:

Acosta, Miguel Leon. La

responsabilidad del empleado público en España. Revista CES Derecho. Vol. 10, No. 2, julio diciembre de 2019, 605-640.

Open access

Términos de uso

Licencia creative commons

Etica de publicaciones

Revisión por pares

Gestión por Open Journal System

DOl: http://dx.doi.org/10.21615/

cesder.10.2.4

ISSN: 2145-7719

Sobre los autores:

1. Candidato a Doctor asistente de investigación en el Área de Derecho Administrativo de la Universidad de Córdoba (España).

\section{Resumen}

Las diferentes responsabilidades del empleado público han sido abordadas por la doctrina. Sin embargo, y a pesar de que todas ellas parten de un mismo fundamento: garantizar el correcto funcionamiento de la Administración y del resto de poderes públicos, estas responsabilidades rara vez se estudian de manera conjunta. La presente investigación propone un examen conjunto a las responsabilidades penal y disciplinaria, con especial atención a los principios sustantivos del ius puniendi y a los matices que sufren en atención a la condición de empleado público. El estudio se completa con la revisión de la responsabilidad patrimonial del empleado público, lo que permite contraponer el distinto grado de protección que este recibe en caso de incurrir en responsabilidad punitiva o patrimonial.

Palabras clave: empleado público, responsabilidad penal, responsabilidad disciplinaria, responsabilidad patrimonial, buen funcionamiento de la Administración.

\section{Abstract}

The different types of liabilities of public servants are often the subject of legal studies. Despite the fact that these types of liability are founded by the common need to ensure the proper functioning of public authorities, they are rarely studied together. This research work proposes a joint exam to criminal and disciplinary liabilities of public employees, with particular regard to the substantive principles of the ius puniendi, and the nuances they experience given the special condition of civil servants. The study is completed with an analysis of the civil liability of public employees, allowing us to compare the degree of protection awarded to public servants in both criminal and civil liability scenarios.

Keywords: Public Servant, Criminal Liability, Disciplinary Liability, Civil Liability, Proper Functioning of the Public Administration.

\section{Introducción}

\subsection{El principio de responsabilidad del empleado público como requisito básico para el buen funcionamiento de la Administración Pública y del resto de poderes públicos}

Los empleados públicos son los principales responsables del buen o mal funcionamiento de la Administración Pública y, en consecuencia, de que se 
cumpla el mandato que la Constitución Española (en adelante, CE) impone a esta de «servir con objetividad los intereses generales, de acuerdo con los principios de eficacia y jerarquía, con sometimiento pleno a la ley y al Derecho» (CE, 1978, art. 103.1)․ En esta lógica, en tanto que los empleados públicos son los que, a través del fenómeno de la imputación, dan vida a la Administración Pública (López Benítez, 1994, p. 262), estos deben desempeñar sus funciones de una manera eficaz ${ }^{2}$, con objetividad ${ }^{3}$, teniendo presente la estructura jerárquica de la Administración como organización y, por supuesto, con pleno sometimiento al ordenamiento. Así ha sido entendido por el legislador, que ha trasladado todos estos principios al régimen jurídico del empleado público [Texto Refundido de la Ley del Estatuto Básico del Empleado Público, aprobado por Real Decreto Legislativo 5/2015, de 30 de octubre (en adelante, TREBEP), 2015, arts. 1.3 y 52 a 54], procurando la satisfacción de los intereses generales conforme al artículo 103.1 CE (de la Torre Martínez et al, 2018, p. 179).

Para garantizar el buen funcionamiento de la Administración Pública no basta, sin embargo, con la declaración de aquellos principios y el establecimiento de los consiguientes deberes de los empleados públicos. Es necesario, además, que se controle su cumplimiento, previniendo y, en su caso, corrigiendo las conductas de los empleados públicos que atenten contra ellos. A tal fin, resulta esencial la consagración del principio de responsabilidad, no solo respecto de la Administración Pública (CE, 1978, art. 9.314, sino también y específicamente de las personas físicas que la integran y actúan a su servicio ${ }^{5}$. Por ello, el legislador consagró, junto con los otros principios ya citados, el de responsabilidad como un principio básico del empleado público (TREBEP, 2015, art. 52).

Asimismo, aunque hasta ahora hayamos hablado únicamente de la Administración Pública y el artículo 103.1 CE solo se refiera a esta, ello no quiere decir que todo lo dicho sea solo aplicable al personal de las Administraciones Públicas en sentido estricto. Por el contrario, sin perjuicio de algunas imprescindibles matizaciones derivadas de su distinta posición constitucional, los principios enunciados deben trasladarse igualmente al régimen del personal al servicio de la Administración de Justicia, del personal de las Cortes Generales y demás asambleas legislativas de las Comunidades Autónomas y al régimen del personal del resto de órganos que reconocen la Constitución y los Estatutos de Autonomía de las Comunidades Autónomas ${ }^{6}$. Así lo entendió el legislador al incorporar los principios del artículo 103.1 CE a los estatutos del personal al servicio de estos poderes y órganos constitucionales;

1. El buen funcionamiento de la Administración se ha venido abordando en los últimos años por la doctrina científica no solo como un deber de la Administración que se infiere del mandato del artículo 103.1 CE, sino también como un derecho de la ciudadanía, al que los mismos autores han tratado de dar contenido. Véanse los trabajos de Tomás Mallén (2004), Rodríguez-Arana Muñoz (2013) y, enfocando la atención en el empleado público, la obra colectiva dirigida por Ponce solé (2018)

2. Este principio sirve como base para explicar muy distintos extremos del régimen jurídico del empleado público. Por un lado, explica la consagración del principio de mérito y capacidad en el acceso al empleo público (CE, 1978, art. 103.3), como destaca Santamaría Pastor (2009, p. 676). Se persigue asi conseguir «un poder competente y virtuoso» (Mauri Majós, 2018, p. 41). Por otro lado, el principio de eficacia justifica también el régimen de incompatibilidades del empleado público que, entre otros fines, pretende evitar que la realización de otras actividades, públicas o privadas, vaya en detrimento del buen desempeño de las funciones del empleado público (Tribunal Constitucional, sentencia 178/1989, 1989, FJ 3). Véase de la Torre Martínez, Izquierdo Carrasco y López Benítez (2018, pp. 191-192).

3. Se trata de una concreción de la interdicción de la arbitrariedad de los poderes públicos (CE, 1978, art. 9.3), que se debe poner en relación con el derecho fundamental de los ciudadanos a la igualdad ante la ley (CE, 1978, art. 14) y el correspondiente mandato a los poderes públicos para procurar la efectividad de dicha igualdad (CE, 1978, art. 9.2).

4. No está de más recordar que los principios del artículo 103.1 CE son de aplicación a todas las Administraciones Públicas españolas, esto es, la Administración General del Estado, las de las Comunidades Autónomas y las Entidades locales, así como también a los entes instrumentales vinculados a todas ellas. Esto con independencia de que el artículo 103 CE se localice en el Título IV «del Gobierno y de la Administración» de la Constitución Española, como señala Nieto García (1992, p. 15). El propio Tribunal Constitucional se muestra tajante al afirmar que se trata de algo incuestionable (Tribunal Constitucional, sentencia 85/1983, FJ 8).

5. Así lo destacan, refiriéndose, en concreto, a la responsabilidad patrimonial, Mir Puigpelat (2002 p. 353) y Fortes González (2014, pp. 30-36). Véase también Díaz y Díaz (2011, pp. 191 y siguientes).

6. Entre ellos, el Tribunal Constitucional (CE, 1978, Título IX), la Casa del Rey (CE, 1978, art. 65), el Defensor del Pueblo (CE, 1978, art. 54), el Tribunal de Cuentas (CE, 1978, art. 136), etc. Nótese que el sometimiento al ordenamiento jurídico y la exigencia de objetividad, expresada como «interdicción de la arbitrariedad», son principios que rigen frente a todos los poderes públicos (CE, 1978, art. 9.1 y 3); y que la eficacia, la jerarquía y la responsabilidad están, en mayor o menor medida, presentes dentro de toda organización, sin perjuicio de la independencia o autonomía de la institución hacia el exterior 7. A modo de ejemplo, es particularmente expresiva la redacción dada al artículo 483 de la Ley Orgánica 6/1985, de 1 de julio, del Poder Judicial (en 7. A mo de

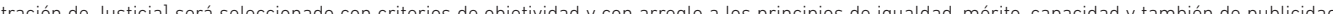
Igual de claro parece a este respecto el artículo 58 del Estatuto del Personal de las Cortes Generales, aprobado por Acuerdo de 27 de marzo de 2006 (en adelante, EPCG) que establece, entre otros, los deberes de guardar acatamiento a la Constitución y al resto del ordenamiento jurídico (letra a), cumplir estricta, imparcial y diligentemente las obligaciones propias del puesto o cargo que ocupen (letra c) y cumplir las órdenes legalmente emanadas de sus 
y al fijar el correspondiente sistema de responsabilidad ${ }^{8}$.

\subsection{El objeto de estudio: los tipos de responsabilidad del empleado público}

El régimen de responsabilidad del empleado público ha sido estudiado en detalle por la doctrina más autorizada y examinada en numerosas ocasiones por la jurisprudencia ordinaria y por el Tribunal Constitucional. Sin embargo, su estudio suele abordarse de manera parcial, centrándose en alguno de los tipos en los que se clasifica generalmente la responsabilidad del empleado público: penal, disciplinaria y patrimonial?

Este trabajo, por el contrario, pretende ofrecer una imagen panorámica y completa de todo el sistema de responsabilidad del empleado público ${ }^{10}$, exponiendo los elementos configuradores de cada una de las responsabilidades que acabamos de mencionar. Para ello, partimos del fundamento base de toda responsabilidad del empleado público: garantizar el correcto funcionamiento de la Administración y del resto de poderes públicos de acuerdo con los principios de eficacia, objetividad, jerarquía y pleno sometimiento el ordenamiento jurídico. A lo largo del trabajo se pondrá de manifiesto cómo la presencia de estos principios modula en una u otra dirección cada tipo de responsabilidad a la que se enfrenta el empleado público. Ello permitirá tener una visión amplia del complejo sistema de responsabilidad al que se someten los empleados públicos y así comprender el porqué de sus peculiaridades respecto al régimen de responsabilidad de un administrado común.

En primer lugar, se abordará la responsabilidad de carácter punitivo, que se identifica con las responsabilidades penal y disciplinaria. Estas dos consisten en la imposición de un castigo -una sanción- al empleado público, acordado por los Jueces y Tribunales del orden penal o por la Administración (u órgano del poder público -legislativo o judicial-) de la que dependa el empleado público. Responden, por tanto, a una finalidad represiva de las conductas contrarias a los principios y deberes de los empleados públicos ya realizadas y preventivas respecto a aquellas que puedan realizar.

En segundo lugar, se expondrán de manera algo más breve los elementos configuradores de la responsabilidad patrimonial del empleado público, cuyo fin principal es la reparación de los daños producidos, es decir, el restablecimiento de la situación ilícitamente alterada sin finalidad punitiva ${ }^{11}$. Su distinta finalidad y su naturaleza civil obligan a tratar a la responsabilidad patrimonial del empleado público de manera separada. De hecho, como se verá, la cualidad de empleado público actúa en este tipo de responsabilidad en sentido contrario al que actúa en la responsabilidad de carácter punitivo.

Finalmente se expondrán las principales conclusiones que resultan del análisis de estos tres tipos de responsabilidad del empleado público. Para alcanzar estos objetivos, se seguirá la metodología jurídica tradicional: un análisis de la normativa reguladora de este sector del ordenamiento jurídico español, incluyendo, con fines

superiores jerárquicos (letra $\mathrm{f}$ )

8. Véanse los artículos 405 a 427, 468 a 469 .bis y 534 a 540 LOPJ y 68 a 73 EPCG.

9. A ellas cabría añadir la responsabilidad política, a la que también se encuentran sometidos quienes ocupan cargos electivos. Esta responsabilidad, sin embargo, y a diferencia de las enunciadas en texto, no surge como consecuencia de una vulneración del ordenamiento jurídico, sino por la pérdida de la confianza del cuerpo político, por lo que no puede considerarse, en rigor, como una forma de responsabilidad jurídica.

10. No será objeto de este trabajo el estudio de las responsabilidades del empleado público que se deriven de las conductas en su ámbito privado y en las que no tenga relevancia la condición de empleado público.

11. No obstante, ello no quiere decir, como acertadamente destaca Fortes González (2014), que la responsabilidad patrimonial del empleado público no tenga una finalidad preventiva. Al contrario, esta «cumple y debe cumplir una función preventiva, tratando de evitar los daños causados por el poder público y sus agentes, mediante el incentivo que la eventualidad de tener que satisfacer una indemnización representay (p. 30). Intimamente relacionada con esta función preventiva, encontramos también en tarespon de la Administración y de los poderes públicos en general. A este respecto, véase también Rebollo Puig (2004, p. 215). 
comparativos, referencias a la regulación contenida en el ordenamiento jurídico colombiano sobre esta misma materia; una revisión de los pronunciamientos del Tribunal Constitucional y del Tribunal Supremo españoles, también puestos en relación con las sentencias más relevantes de la Corte Constitucional colombiana; y un análisis de la principal doctrina científica, fundamentalmente española, pero también colombiana, que ha abordado el estudio de estas materias.

\subsection{El concepto de empleado público}

Antes de entrar en el estudio de los diferentes tipos de responsabilidad del empleado público, se debe aclarar, sin embargo, qué entendemos por «empleado público»a los efectos de este trabajo y qué relevancia tiene la cualidad de empleado público en la responsabilidad que estos asumen cuando desempeñan sus funciones.

Lo primero que se debe hacer notar es que no existe un único concepto de empleado público, común a todo el ordenamiento jurídico español, sino que cada rama de este ordenamiento cuenta con un concepto de empleado público propio, aplicable únicamente a sus propios efectos.

Así, en el Derecho Administrativo y, en concreto, en el régimen disciplinario, se maneja un concepto formal de empleado público, recogido en el TREBEP, según el cual son empleados públicos «quienes desempeñan funciones retribuidas en las Administraciones Públicas al servicio de los intereses generales» (TREBEP, 2015, art. 8.11)2. En cambio, el Derecho Penal se aleja de este concepto del Derecho Administrativo y se sirve de un concepto material o funcional cuyo alcance es mucho mayor ${ }^{13}$. Incluso dentro del propio Derecho Administrativo, el concepto de empleado público puede variar. De hecho, en el régimen de responsabilidad patrimonial se emplea igualmente un concepto material, de mayor alcance que en el régimen disciplinario ${ }^{14}$.

Así, por ejemplo, el presidente de una entidad de derecho privado de capital público puede responder penalmente como empleado público ${ }^{15}$, pero, paradójicamente, no está sometido al régimen administrativo disciplinario al no encajar en el concepto de empleado público del artículo 8.1 TREBEP ${ }^{16}$. Del mismo modo, ciertos cargos políticos, sin ser empleados públicos a efectos del TREBEP17, podrían ser considerados como tales a efectos de responsabilidad penal y patrimonial si ejercieran funciones públicas ${ }^{18}$.

Hechas estas salvedades, aún debe hacerse una última aclaración metodológica. El personal al servicio de las Cortes Generales y de las asambleas legislativas de las Comunidades Autónomas, de la Administración de Justicia y de los demás órganos constitucionales serán considerados a efectos de este trabajo como empleados públicos,

12. Su apartado segundo concreta esta definición clasificando a los empleados públicos en cuatro categorías: a) funcionario de carrera, vinculado, con carácter permanente, a la Administración a través de una relación estatuaria (TREBEP. 2015, art. 9.1): b) funcionario interino, que ejerce las funciones del funcionario de carrera de manera temporal por razones de urgencia y necesidad (TREBEP, 2015, art. 10.1); c) personal laboral, vinculado a la Administración por medio de un contrato laboral (TREBEP, 2015, art. 11.1); y d) personal eventual, nombrado para ejercer funciones «de confianza o asesoramiento especial» (TREBEP, 2015, art. 12.1).

13. El artículo 24.2 del Código Penal (en adelante, CPen), establece que «se considerará funcionario público todo el que por disposición inmediata de la Ley o por elección o por nombramiento de autoridad competente participe en el ejercicio de funciones públicas».

14. Según García de Enterría y Fernández (2015b), no solo se consideran empleados públicos a efectos de responsabilidad patrimonial a aquellos que lo son en sentido estricto, sino a «cualesquiera otros agentes que por un título u otro desempeñen, aunque sea de modo ocasional, funciones [públicas]» ( $p$. 393) (ex LRJSP, 2015, art. 36).

15. Fue el caso de la sentencia del Tribunal Supremo (en adelante, STS) 1590/2003, FJs 13, 14 y 15, en la que el presidente de IMPROASA, una sociedad mercantil de capital público, fue condenado por los delitos de fraude y cohecho, recibiendo la consideración de empleado público. Véanse Echevarría (2019, pp. 20-24) y Muñoz Conde (2015, p. 843)

16. Nótese que, según el artículo 2 de la Ley 40/2015, de 1 de octubre, de Régimen Jurídico del Sector Público (en adelante. LRJSP) y el artículo 2 TREBEP, estas entidades de derecho privado dependientes o vinculadas a una Administración pública, no son propiamente una Administración pública y, por tanto sus trabajadores no son considerados empleados públicos. Cuestión distinta podría ser el caso de la responsabilidad patrimonial respecto a los empleados de este tipo de entidades, dado el carácter material del concepto de empleado público a efectos de responsabilidad patrimonial (Fortes González, 2014 pp. 138-141).

17. Esta afirmación debe ser matizada por cuanto el TREBEP prevé como empleados públicos a las personas que son nombradas por las autoridades para asesorarlos; inclusión que, por otra parte, ha sido duramente criticada, con razón, por la doctrina. Entre la misma destaca Fernández Ramos (2013). 18. Esta posibilidad, sin embargo, no está exenta de crítica. Al respecto puede verse a Barcelona Llop, (2000, pp. 40 y siguientes), quien expone los problemas que un régimen unitario entre autoridades (cargos políticos) y empleados públicos puede generar. 
aun no siendo empleados de la Administración. Esta parece la solución más acorde con los conceptos funcionales de empleado público que se manejan para la responsabilidad penal y la responsabilidad patrimonial, a lo que se añade que los regímenes disciplinarios de unos y otros empleados son extremadamente similares, cuando no coincidentes $^{19}$, sin perjuicio de las lógicas peculiaridades de cada uno.

\section{Responsabilidad de carácter punitivo del empleado público}

\subsection{El Derecho Penal y el Derecho Administrativo Sancionador: un ordenamiento punitivo único}

En España, la principal consecuencia para el empleado público por el incumplimiento de alguno de los deberes derivados de tal condición es la posibilidad de ser sancionado. Sanción que puede ser penal, impuesta por los Jueces y Tribunales, de conformidad con el Derecho Penal; o disciplinaria, impuesta por la Administración empleadora, de acuerdo con el Derecho Administrativo Sancionador, en el que se integra ${ }^{20}$.

Si se repara en lo dicho, se puede afirmar que estamos ante dos manifestaciones del ius puniendi del Estado, personificado en su ejercicio bien en los Jueces y Magistrados que integran el Poder Judicial, o bien en la Administración pública. Y, por ende, podemos hablar de un mismo ordenamiento punitivo, sometido a unos principios y reglas comunes, sin perjuicio de que presente peculiaridades en sus diferentes vertientes ${ }^{21}$.

En efecto, el Derecho Penal y el Derecho Administrativo Sancionador tratan, mediante la imposición de sanciones, de salvaguardar ciertos bienes jurídicos que el Poder constituyente y el legislador han considerado dignos de protección ${ }^{22}$. En el caso que nos ocupa, el bien jurídico protegido, tanto por el Derecho Penal como por el Derecho Administrativo Sancionador, es la Administración pública y, en especial, su correcto funcionamiento ${ }^{23}$, concretado habitualmente en la observancia de los principios de objetividad y eficacia (artículo 103.1 CE) ${ }^{24}$. Y ello sin perjuicio de que se protejan, a la vez, otros bienes jurídicos imbricados en el buen funcionamiento de la Administración ${ }^{25}$

19. Especialmente ilustrativo es el artículo 68.3 EPCG, el cual dispone que las faltas disciplinarias del personal de las Cortes Generales «serán las mismas que las establecidas con carácter general para la función pública», es decir, para el personal funcionario regulado en el artículo 9.1 TREBEP.

20. A nuestros efectos, hablar de Derecho Administrativo Sancionador aplicable a los empleados públicos y de Derecho Disciplinario de los empleados públicos es hablar de la misma rama del ordenamiento jurídico, pues existe una identificación perfecta entre ellos. En línea con lo defendido por Rincón Córdoba, el hecho de que el régimen disciplinario presente peculiaridades (derivadas de la relación especial de sujeción entre administrado y Administración) no implica la autonomía respecto a la rama del Derecho que le sirve de referente -el Derecho Administrativo Sancionador- sino la aplicación, en su caso, de reglas especiales que atiendan dichas peculiaridades. Estas reglas especiales son las que justifican el estudio del régimen disciplinario por separado, pero siempre dentro del marco del Derecho Administrativo Sancionador al que pertenece. Esto que no se discute por la doctrina española, todavía supone una cuestión abierta en otros países como Colombia en el que el régimen disciplinario ha sido tratado como una materia autónoma del Derecho Administrativo Sancionador. Como ejemplo, puede verse a Gómez Pavajeau (2011). En sentido opuesto, y en línea con la doctrina española, encontramos la excelente obra de Rincón Córdoba, (2018, pp. 39-73).

21. En este sentido se pronunció la temprana sentencia del Tribunal Constitucional (en adelante, STC) 18/1981, FJ 2. Debe aclararse que, en el caso de España, el Tribunal Constitucional únicamente reconoce dos posibles manifestaciones del ius puniendi del Estado: el Derecho Penal y el Derecho Administrativo Sancionador. Se diferencia, de esta forma, de la postura defendida en Colombia por la Corte Constitucional, que identifica hasta cinco vertientes de dicho ius puniendi: el Derecho Penal, el Derecho Contravencional, el Impeachment, el Derecho Correccional y el Derecho Disciplinario, tal y como se recoge desde su más temprana jurisprudencia en las sentencias C-195 de 1993, C-214 de 1994, C-280 de 1996, C-306 de 1996, C-597 de 1996, C-310 de 1997, C-554 de 2001, C-827 de 2001, C-406 de 2004, C-948 de 2002, C-818 de 2005, T-1034 de 2006 y T-068 de 2009. Desde el punto de vista del ordenamiento jurídico español, el Derecho Contravencional, el Derecho Correccional y el Derecho Disciplinario, sin perjuicio de sus respectivas peculiaridades, se consideran simples modalidades del Derecho Administrativo Sancionador, mientras que el Impeachment se considera una forma de responsabilidad política, pero no jurídica.

22. A este respecto, no puede dibujarse una frontera clara, ni cuantitativa ni cualitativa, que permita identificar qué bienes jurídicos o en qué grado son protegidos por una rama del Derecho u otra, dejándose esta decisión, salvo casos muy concretos, al legislador (Rebollo Puig, 2010a, pp. 53-55; Alarcón Sotomayor, 2014, pp. 135-167)

23. En menor medida, también se han considerado dignos de protección, tanto por el Derecho Penal como por el Derecho Administrativo Sancionador, otros bienes jurídicos como la propia imagen de la Administración y la confianza que emana hacia los administrados [Tribunal Supremo, sentencia 161/2002. FJ 2, en relación con el delito del artículo 438 CPen; y sentencia 2614/2016. FJ 7, en relación con la falta disciplinaria muy grave del artículo 417.14 LOPJ] o el patrimonio de la Administración [Tribunal Supremo, sentencia 910/1997, FJ 2, en relación con el delito de fraude del artículo 439 CPen]. También, en relación con ambos bienes jurídicos, encontramos la STS 211/2006, FJ 8, respecto al delito de malversación del artículo 432 CPen.

24. Tales serían los bienes jurídicos protegidos específicamente, por ejemplo, en el delito de tráfico de influencias del artículo 428 CPen [Tribunal Supremo, sentencia 300/2012, FJ 11] o en el delito de cohecho del artículo 419 CPen [Tribunal Supremo, sentencia 1076/2006, FJ 28]. O, en el caso del Derecho Administrativo Sancionador, en la falta muy grave consistente en "la violación de la imparcialidad, utilizando las facultades atribuidas para influir en procesos electorales de cualquier naturaleza y ámbito" [TREBEP, 2015, art. 95.2.h)].

25. Nótese, especialmente, la importancia en este ámbito de algunos bienes jurídicos protegidos como el derecho a la igualdad (CE, 1978, art. 14), que constituiría el reverso del deber de objetividad (CE, 1978, art. 103.1). Por tanto, la protección de la actuación objetiva de la Administración lleva irremedia- 


\subsection{El sistema de fuentes del Derecho Penal y el Derecho Administrativo Sancio- nador. En particular, el régimen disciplinario del empleado público}

\subsubsection{La Constitución Española y los tratados internacionales}

Como cualesquiera otros sectores del ordenamiento jurídico español, el Derecho Penal y el Derecho Administrativo Sancionador se hayan sujetos en primer lugar y ante todo a la Constitución Española (CE) y a los derechos fundamentales que consagra; en particular, a lo dispuesto por los artículos 24 y 25 CE, que recogen las garantías -en rigor, derechos fundamentales- frente al ejercicio del ius puniendi del Estado. Además, estos derechos fundamentales deben ser interpretados «de conformidad con la Declaración Universal de Derechos Humanos y los tratados y acuerdos internacionales ratificados por España» (artículo 10.2 CE). Dentro de estos tratados y acuerdos, deben destacarse el Convenio Europeo de Derechos Humanos (CEDH) y la Carta de los Derechos Fundamentales de la Unión Europea (CDFUE), así como la jurisprudencia emanada del Tribunal Europeo de Derechos Humanos (TEDH) y del Tribunal de Justicia de la Unión Europea (TJUE), intérpretes últimos de ambos textos ${ }^{26}$.

\subsubsection{Normativa con rango de ley. La codificación de las normas penales y la dispersión de las normas administrativas sancionadoras}

En el ordenamiento jurídico español encontramos que el legislador ha codificado, si no todas, al menos sí la inmensa mayoría de normas penales en un solo texto legal: el Código Penal, aprobado por la Ley Orgánica 10/1995, de 23 de noviembre. La mayor excepción que encontramos a este respecto es el Código Penal Militar, aprobado por Ley Orgánica 14/2015, de 14 de octubre; excepción que responde a razones históricas y a las peculiares características del ámbito castrense ${ }^{27}$.

Consciente de la importancia del buen funcionamiento, imagen y patrimonio de la Administración pública, el legislador no ha reparado en esfuerzos para establecer un exhaustivo listado de delitos especiales previstos para corregir a los empleados públicos y las conductas de estos que atenten contra alguno de los bienes jurídicos mencionados ${ }^{28}$. Estos delitos que atienden a la condición de empleado público, en su mayoría, se concentran en los Títulos XIX de los «Delitos contra la Administración pública» (CPen, 1995, arts. 404 a 445) y XX de los «Delitos contra la Administración de Justicia» (CPen, 1995, arts. 446 a 471 bis), así como en el Capítulo $V$ «De los delitos cometidos por los funcionarios públicos contra las garantías constitucionales», del Título XXI de los «Delitos contra la Constitución» (CPen, 1995, arts. 529 a 542).

Frente a lo que ocurre en el Derecho Penal, no hay en el Derecho Administrativo Sancionador texto alguno que haga las veces del Código Penal o que siquiera recoja una parte general que sea aplicable a toda infracción y sanción administrativa. Solo existe una mera enumeración de los principios de la potestad sancionadora de la

Administración pública (LJRSP. 2015, arts. 25 a 31). Así las cosas, es preciso acudir a blemente aparejada la protección de este derecho. Por ejemplo, la prevaricación de un empleado público (CPen, 1995, art. 404) por la que se haya originado una resolución arbitraria conculcará el derecho a la igualdad de los administrados afectados. Así mismo, en el régimen disciplinario, se puede apreciar. además, la protección de otros bienes jurídicos como el derecho a la sindicación, a la huelga, o a la libertad sexual (TREBEP, 2015, art. 95.2).

26. Estos textos no solo orientan la interpretación de la Constitución, sino que, en tanto que son Tratados Internacionales válidamente celebrados y publicados en España, sus disposiciones son directamente vinculantes para el Estado en el ejercicio de su ius puniendi (CE, 1978, art. 96.1; y Tratado de Funcionamiento de la Unión Europea, 2010, art. 6).

27. También podemos encontrar otras normas penales, fuera del Código Penal, como el Capítulo VIII del Título I de la Ley Orgánica 5/1985, de 19 de junio del Régimen Electoral General (arts. 135 a 153), dedicado a los «Delitos e infracciones electorales».

28. Conviene aquí hacer una precisión, de especial importancia a efectos de non bis in idem, como más adelante se verá. Los delitos especiales de los empleados públicos pueden clasificarse en propios e impropios. Los primeros corresponden a delitos que únicamente pueden cometer los empleados públicos en razón de su condición. Por ejemplo, el delito de prevaricación, en tanto consiste en dictar una resolución administrativa, conducta que solo puede ser adoptada por un empleado público [Tribunal Supremo, sentencia 406/2004, FJ 3]. Los delitos especiales impropios, por el contrario, son delitos que tipifican conductas que igualmente están tipificadas como delitos comunes. Sería el caso del delito de descubrimiento y revelación de secretos (CPen, 1995, art. 197) que, si se comete por un empleado público conllevaría una pena agravada (CPen, 1995, art. 198) [Tribunal Supremo, sentencia $725 / 2004$. FJ 11]. Son los primeros - los delitos especiales propios- los que realmente tienen por bien jurídico protegido a la Administración, mientras que los delitos especiales impropios protegen una amplia variedad de valores o intereses, diferentes al representado por la Administración, actuando estos delitos especiales impropios como un subtipo agravado del delito común [Tribunal Supremo, sentencia de 30 de mayo de 2000, FJ 3] 
cada sector concreto del ordenamiento administrativo para buscar, en su normativa propia, el régimen sancionador que resulte aplicable. En nuestro caso, lo anterior implica que, a fin de conocer el régimen disciplinario de los empleados públicos, es preciso acudir a la normativa sectorial reguladora del empleo público. Ahora bien, el sistema de fuentes español en materia de empleo público es tremendamente complejo, lo que determina que el régimen jurídico disciplinario de los empleados públicos también lo sea. En efecto, a diferencia de lo que acontece en Colombia, no existe en España ninguna norma equiparable a la Ley 734 de 2002 (Código Disciplinario Único) o a la nueva Ley 1952 de 2019 (Código General Disciplinario, actualmente en periodo de vacatio legis y que sustituirá a la anterior a partir de julio de 2021).

El sistema de fuentes español en materia de empleo público y, específicamente, en materia de régimen disciplinario de los empleados públicos, toma como punto de partida el ya indicado Real Decreto Legislativo 5/2015, de 30 de octubre, por el que se aprueba el texto refundido de la Ley del Estatuto Básico del Empleado Público (TREBEP), que se encarga en este ámbito de fijar unas normas de mínimos que deberán ser desarrolladas en otras leyes ${ }^{29}$.

El Título VII del "Régimen disciplinario" (TREBEP, 2015, arts. 93 a 98) establece los empleados sujetos a este régimen, los principios del ejercicio de la potestad disciplinaria, las faltas y sanciones, la prescripción de ambas y el procedimiento disciplinario. Es de destacar, sin embargo, que, en relación con las faltas, el TREBEP solo tipifique las faltas muy graves (TREBEP, 2015, art. 95.2), remitiendo la tipificación de las faltas graves y leves a otras normas con rango de ley ${ }^{30}$.

A pesar de establecer algunos principios comunes, el TREBEP establece una división de regímenes disciplinarios entre aquel aplicable a los funcionarios públicos y el aplicable al personal laboral de la Administración ${ }^{31}$. Las leyes que deben completar y desarrollar este régimen disciplinario respecto a los funcionarios públicos son las Leyes de Función Pública que aprueben las Cortes Generales y las asambleas legislativas de cada Comunidad Autónoma (TREBEP, 2015, arts. 6 y 95.3 y 4) ) $^{32}$. En cuanto al régimen disciplinario del personal laboral, este se regirá, en lo no previsto por el TREBEP, por la legislación laboral general (TREBEP, 2015, art. 93.4), es decir, la aplicable a los trabajadores por cuenta ajena contratados por empleadores privados. Se debe acudir, pues, al Estatuto de los Trabajadores (Real Decreto Legislativo 2/2015, de 23 de octubre, por el que se aprueba el texto refundido de la Ley del Estatuto de los Trabajadores - TRLET) y a los respectivos Convenios Colectivos aprobados en cada Administración. Lo cierto es, sin embargo, que salvo el despido disciplinario (TRLET, 2015, art. 58), el Estatuto de los Trabajadores no aborda apenas el régimen disciplinario. De esta forma, y en la práctica, el legislador estatal ha confiado a los Convenios Colectivos, acordados entre cada Administración y su respectivo personal laboral, el desarrollo del TREBEP y, en especial, la tipificación de las faltas disciplinarias graves y leves (TREBEP, 2015, art. 95.3 y 4).

29. Al margen de esta norma, el legislador ha regulado de manera independiente el régimen disciplinario del personal al servicio de la Administración de Justicia (LOPJ, 1985, arts. 414 a 427, 468 a 469.bis y 534 a 540) y del personal de las Cortes Generales y del resto de asambleas legislativas de las Comunidades Autónomas (respecto al personal de las Cortes Generales, EPCG, 2006, arts. 68 a 73). Además, también se encuentra regulado de forma separada el régimen disciplinario de algunos cuerpos de empleados públicos en sentido estricto. Entre estos regímenes destacan el del personal militar de las Fuerzas Armadas (Ley Orgánica 8/2014, de 4 de diciembre, de Régimen Disciplinario de las Fuerzas Armadas, LORDFAS), que se completa con el de la Guardia Civil (Ley Orgánica 12/2007, de 22 de octubre, del régimen disciplinario de la Guardia Civil, LORDGC); y el del personal de las Fuerzas y Cuerpos de Seguridad (Ley Orgánica 4/2010, de 20 de mayo, del régimen disciplinario del Cuerpo Nacional de Policía, LORDCNP).

30. Estas normas de desarrollo deberán atender, en todo caso, a: a) el grado en que se haya vulnerado la legalidad; b) la gravedad de los daños causados al interés público, patrimonio o bienes de la Administración o de los ciudadanos; y c) el descrédito para la imagen pública de la Administración (TREBEP, 2015, art. 95.3 y 4).

31. Respecto a esta diversidad de regímenes entre los empleados públicos, y los problemas interpretativos que puede causar, se muestra crítico Cámara del Portillo (2008, p. 89).

32. Sin embargo, el propio legislador estatal no ha cumplido aún este mandato por él mismo impuesto, no habiéndose aprobado todavía ley estatal que desarrolle el régimen disciplinario de los funcionarios públicos al servicio de la Administración General del Estado. En esta misma línea, solo cinco han sido las Comunidades Autónomas que han aprobado sus propias Leyes de Función Pública en desarrollo del TREBEP. 
2.2.3. Normativa con rango reglamentario. La colaboración reglamentaria en el Derecho Administrativo Sancionador y, en concreto, en el ámbito disciplinario

Al contrario que en el Derecho Penal, la colaboración reglamentaria en el Derecho Administrativo Sancionador es común y por todos aceptada (Nieto García, 2012, p. 223). En el ámbito disciplinario de los empleados públicos tiene un papel principal el Reglamento de Régimen Disciplinario de los Funcionarios de la Administración General del Estado, aprobado por Real Decreto 33/1986, de 10 de enero (en adelante, RRD) que, a falta de una norma con rango de ley, es el único texto que tipifica las faltas graves y leves de los funcionarios públicos de la Administración General del Estado en sus artículos 7 y 8, cuyo tenor suele ser reproducido por los Convenios Colectivos que establecen estas faltas para el personal laboral de las Administraciones correspondientes (Bueno Armijo, 2018a, p. 248). Igualmente, a falta de la aprobación de las Leyes de Función Pública de las Comunidades Autónomas, el RRD es de aplicación a los funcionarios públicos de aquellas, debido al carácter supletorio de la normativa estatal (CE, 1978, art. 149.3).

\subsection{Los principios y reglas sustantivos del lus Puniendi y la incidencia en estos de la condición de empleado público}

Como se dijo más arriba, el Derecho Penal y el Derecho Administrativo Sancionador son manifestaciones del ius puniendi único del Estado. Ambos pertenecen a un mismo ordenamiento punitivo $y$, en consecuencia, comparten una comunidad de principios y reglas que se desprenden de la propia Constitución Española, en particular, de los artículos 24 y $25 \mathrm{CE}^{33}$. Igualmente, en ambos sectores del ordenamiento se producen ciertas matizaciones en el seno de las relaciones de sujeción especial, en nuestro caso, las de los empleados públicos en el desempeño de sus funciones, como tendremos ocasión de poner de manifiesto.

Ello, no obstante, no significa, como ya se encargó de indicar la jurisprudencia desde un principio, que se deban aplicar mecánicamente todas las elaboraciones desarrolladas en el orden penal al orden administrativo sancionador, ni a la inversa, ni que los principios que sí resulten comunes se interpreten de igual manera en ambos ámbitos ${ }^{34}$. Tampoco significa, en la misma lógica, que esas matizaciones de las que hablamos respecto a las relaciones de sujeción especial se den en el mismo grado en uno y otro orden punitivos. La influencia de este tipo de relaciones en la atenuación de los principios que ahora analizaremos resulta más clara en el Derecho Administrativo Sancionador $-y$, especialmente, en el Derecho disciplinario que se incardina en aquel-, que en el Derecho Penal.

En este epígrafe, por cuestiones de extensión, nos centraremos en el estudio de los principios sustantivos del ius puniendi recogidos en el artículo 25 CE, haciendo hincapié en las relajaciones que algunos de estos principios sufren por motivo de la condición de empleado público de los sujetos sancionados, penal o administrativamente, por su especial posicionamiento dentro de la Administración en la que prestan sus servicios y las consecuencias que esto acarrea (v.gr., la relajación de los principios de legalidad sancionadora por el especial conocimiento que deben tener de sus deberes y funciones).

33. Así lo viene afirmando el Tribunal Constitucional desde sus primeras sentencias, como la STC 18/1981, FJ 2. Como decimos, los principios que se describen en este epígrafe son comunes a ambos sectores del ordenamiento, no el resultado de trasladar principios y reglas del Derecho Penal al Derecho Administrativo Sancionador (Rebollo Puig, 2010a, pp. 49-55). En este mismo sentido se expresa, respecto al caso del ordenamiento jurídico peruano, (Baca Oneto, 2019, pp. 314-317). Como explica el autor, los principios enumerados en el artículo 246 del Texto Único Ordenado de la Ley 27444 , Ley del Procedimiento Administrativo General, aprobado mediante el Decreto Supremo 006-2017-Jus son principios comunes del ius puniendi; $y$ «no principios del Derecho Penal que se aplican al Derecho Administrativo [Sancionador]».

34. En este sentido se pronunció la propia STC 18/1981, FJ 2: y poco más tarde, la STC 76/1990, FJ 4. 
Conforme a lo dicho, la comunidad de principios del Derecho Penal y el Derecho Administrativo Sancionador resulta evidente en el artículo 25.1 CE cuyo tenor hace referencia a ambas manifestaciones del ius puniendi del Estado:

«Nadie puede ser condenado o sancionado por acciones u omisiones que en el momento de producirse no constituyan delito, falta o infracción administrativa, según la legislación vigente en aquel momento» ${ }^{35}$.

A partir de este precepto, el Tribunal Constitucional, la jurisprudencia y la doctrina científica han inferido varios principios (en rigor, derechos fundamentales o, al menos, elementos del derecho fundamental a la legalidad sancionadora) y los han dotado de contenido propio y distinto ${ }^{36}$. A tales efectos, se han servido del "supra-concepto" de ilícito, aplicable en ambos sectores del ordenamiento (lo que permite hablar de ilícito penal y de ilícito administrativo) y al que se entienden aplicables todos los principios que garantizan el correcto ejercicio (material) del ius puniendi por parte del Estado. Este supra-concepto ha sido definido como el resultado de una conducta - positiva u omisiva- típica, antijurídica y culpable. Los principios derivados de este concepto y el contenido del artículo 25.1 CE serán expuestos siguiendo esta definición.

\subsubsection{Principio de legalidad}

Sin perjuicio de otros principios que se puedan inferir del transcrito artículo 25.1 $\mathrm{CE}$, el principio al que este hace referencia expresa es el que la doctrina y la jurisprudencia han denominado principio de legalidad, que, como ya dijera el Tribunal Constitucional, abarca, en realidad, una triple garantía: el principio de irretroactividad de la norma sancionadora desfavorable, el principio de tipicidad y el principio de reserva de ley (Tribunal Constitucional, sentencia 8/1981, FJ 3).

Las dos primeras garantías, «de orden material», concretan, en el ámbito sancionador, el principio de seguridad jurídica consagrado en el artículo 9.3 CE. Estas dos garantías (irretroactividad de la norma sancionadora desfavorable y tipicidad de la conducta sancionable), como explica muy bien el Tribunal Supremo (sentencias de 20 de diciembre de 1999, FJ 5; y de 26 de junio de 2001, FJ 4), suponen

«la exigencia imperiosa de predeterminación normativa de las conductas infractoras y de las sanciones correspondientes, es decir, la existencia de preceptos jurídicos (lex praevia) y que permitan predecir con suficiente grado de certeza (lex certa) aquellas conductas infractoras y se sepa a qué atenerse en cuanto a la aneja responsabilidad y a la eventual sanción».

La tercera garantía es «de carácter formal, relativa a la exigencia de que exista una norma del suficiente rango que se identifica con el rango legal» ${ }^{37}$.

De hecho, la identificación de esta triple garantía hecha por la doctrina constitucional, la jurisprudencia y la doctrina científica ha sido reflejada por el legislador en los artículos 25 a 27 de la Ley 40/2015, de 1 de octubre, de Régimen Jurídico del Sector

35. En términos muy similares se expresan los artículos 11.2 DUDH, 7.1 CEDH y 49.1 CDFUE. Por su parte, cabe señalar como equivalente a estos preceptos el artículo 29 de la Constitución Política de Colombia: «El debido proceso se aplicará a toda clase de actuaciones judiciales y administrativas. Nadie podrá ser juzgado sino conforme a leyes preexistentes al acto que se le imputa, ante juez o tribunal competente y con observancia de la plenitud de las formas ser juzgado sino conforme a leyes preexistentes al acto que se le imputa, ante juez o tribunal competente y con observancia de la plenitud de las formas
propias de cada juicio».

36. En rigor, y como ya señaló (Nieto García, 2012), el artículo 25.1 CE solo enuncia, propiamente, el principio de irretroactividad de la norma sancionadora desfavorable. El autor encuentra este caso «un ejemplo paradigmático de la forma de proceder de algunos juristas: allí donde encuentran un elemento (aunque sea único) de una figura jurídica (la irretroactividad suele ser considerada como manifestación del principio de la legalidad) la reconstruyen en su integridad (...). Pero ni que decir tiene que esto es puro voluntarismo: no buscando el Derecho sino creándolo -o mejor aún imaginándoselo- a su gusto» (p. 170).

37. En este mismo sentido se ha mantenido constante la doctrina del Tribunal Constitucional (por todas, STC 13/2013, FJ 2). 
Público (LRJSP), aplicable a todas las Administraciones públicas españolas ${ }^{38}$.

\section{a) Principio de irretroactividad}

La irretroactividad de la norma sancionadora desfavorable es un principio básico -y lógico- en cualquier Estado de Derecho, que no puede castigar a ninguno de sus ciudadanos sin que la conducta que se pretende sancionar se encuentre recogida con carácter previo a dicha conducta en una norma -vigente- del ordenamiento jurídico. En palabras del Tribunal Constitucional, este principio constituye «la garantía del ciudadano de que no será sorprendido a posteriori con una calificación de delito o con una pena no prevista o más grave que la señalada al tiempo del hecho» (Tribunal Constitucional, sentencia 21/1993; y 116/2007). El mismo efecto sorpresivo tendría la ultraactividad de un precepto que ya no se encontrase vigente en el momento de producirse los hechos, bien por su derogación, bien por su anulación en sede judicial. La aplicación de ese precepto infringiría el principio de irretroactividad, expresado con el aforismo nullum crimen nulla poena sine lege praevia ${ }^{39}$.

Este principio constitucional ha sido igualmente consagrado por tratados internacionales como la DUDH (artículo 11.2), el CEDH (artículo 7.1) y la CDFUE (artículo 49.1) y se le ha dado trasladado a la legislación ordinaria tanto en el orden penal (CPen, 1995, arts. 1.1 y 2.1) como en el administrativo sancionador (LRJSP, 2015, art. 26.1). Asimismo, en el régimen disciplinario aplicable a los empleados públicos españoles este principio es recogido también expresamente en el artículo 94.2.b) TREBEP:

«La potestad disciplinaria se ejercerá de acuerdo con los siguientes principios (...): b) Principio de irretroactividad de las disposiciones sancionadoras no favorables y de retroactividad de las favorables al presunto infractor ${ }^{40}$.

En efecto, la proclamación de este principio ha sido más que reiterada por el legislador y su aplicación poco discutida por la doctrina, lo que probablemente explique, como señala Bueno Armijo (2010c, p. 203), la «mínima, cuando no inexistente» litigiosidad de este principio.

De conformidad con todo lo dicho, el principio de irretroactividad de la norma sancionadora lo es respecto a las «disposiciones sancionadoras no favorables», como expresamente establece el artículo 9.3 CE. Ello también ha llevado a interpretar contrario sensu al Tribunal Constitucional la consagración, dentro de la Constitución Española, de «la retroactividad de la Ley penal o sancionadora más favorable» (Tribunal Constitucional, sentencia 85/2006) ${ }^{41}$; interpretación que se vio reforzada tras la entrada en vigor de las disposiciones de la CDFUE y, en concreto, del artículo 49.1 CDFUE ${ }^{42}$.

Igualmente, esta vertiente de la retroactividad de la norma sancionadora más favorable encuentra su reconocimiento en la legislación ordinaria. Así, en el orden penal el artículo 2.2 CPen establece que «tendrán efecto retroactivo aquellas leyes penales que favorezcan al reo, aunque al entrar en vigor hubiera recaído sentencia firme

38. El traslado de dichas garantías a la legislación ordinaria ya tuvo lugar en la Ley anterior a la LRJSP: la Ley 30/1992, de 26 de noviembre, de Régimen Jurídico de las Administraciones Públicas y del Procedimiento Administrativo Común (artículos 127 a 129).

39. A modo de ejemplo, la STC 195/2005, de 18 de julio, declaró la nulidad de una sanción disciplinaria impuesta a un miembro del Cuerpo Nacional de Policía por la comisión de una infracción tipificada en el artículo 7.2 del Reglamento de régimen disciplinario del Cuerpo Nacional de Policía, aprobado por Real Decreto 884/1989, de 14 de julio; ello porque el artículo había sido anulado por la STS de 26 de septiembre de 1996 , Sección $7^{\text {a }}$ de la Sala de lo Contencioso-administrativo, previa al momento de producirse los hechos sancionados.

40. El mismo principio puede encontrarse igualmente en Colombia, en el aún vigente artículo 4 del Código Disciplinario Único - Ley 734 de 2002 («El servidor público y el particular en los casos previstos en este código sólo serán investigados y sancionados disciplinariamente por comportamientos que estén descritos como falta en la ley vigente al momento de su realización») y, aún con mejor técnica legislativa, en el nuevo artículo 4 del Código Genera Disciplinario - Ley 1952 de 2019

41. Esta hace sentencia a la doctrina recogida en sus sentencias 8/1981, 156/1981,51/1985, 177/1994, 129/1996 y 215/1998.

42. Este precepto establece que «si con posterioridad a la infracción la ley dispone una pena más leve, deberá aplicarse esta». 
y el sujeto estuviese cumpliendo condena» ${ }^{43}$. En una línea muy similar, también se expresan en el ámbito administrativo sancionador y disciplinario los artículos 26.2 LRJSP y 94.2 b) TREBEP, antes transcrito ${ }^{44}$.

Tampoco esta vertiente del principio de irretroactividad es discutida en la actualidad, más allá de la determinación de la ley efectivamente más favorable para el infractor; y, lo que más nos importa en este trabajo, ninguna de las dos vertientes del principio presenta especialidades para el caso de los empleados públicos.

\section{b) Principio de tipicidad}

El principio de tipicidad, al contrario que el principio de irretroactividad, sí ha precisado de un extenso desarrollo doctrinal y jurisprudencial. Como decíamos más arriba, estos principios, de orden material, están íntimamente relacionados con el principio de seguridad jurídica (CE, 1978, art. 9.3), que exige que el ciudadano tenga conocimiento en todo momento sobre «qué conductas son constitutivas de infracción -penal o administrativa- y cuáles son las sanciones aplicables a ellas». Para ello, recordemos, no basta con la simple preexistencia de preceptos jurídicos (lex praevia), sino que estos «permitan predecir con suficiente grado de certeza» las consecuencias de tales conductas (Tribunal Supremo, sentencia de 11 de abril de 2003, FJ 3). De esta premisa se derivan dos mandatos a los poderes públicos: el principio de taxatividad y el principio de tipicidad en sentido estricto. El primero de ellos va dirigido a los «redactores» de las normas sancionadoras: el legislador y la Administración -esta última en el ejercicio de su limitada potestad reglamentaria-, quienes deberán ser lo más precisos y claros que resulte posible en la descripción de las conductas que se tipifiquen como ilícitos, en las sanciones que pueden imponerse y en los criterios que conectan unos y otras. El segundo mandato está dirigido a los aplicadores del Derecho, quienes solo podrán sancionar aquellas conductas que se identifiquen y coincidan claramente con los comportamientos tipificados en la norma sancionadora.

\section{a) Principio de taxatividad}

Conforme a este principio, las normas sancionadoras deben contener «los elementos suficientes como para caracterizar una conducta concreta y que esta pueda ser claramente identificada por los ciudadanos» (Bueno Armijo, 2010b, pp. 164-165) 45 para que estos «puedan conocer de antemano el ámbito de lo prohibido y prever, así, las consecuencias de sus acciones» (Tribunal Constitucional, sentencias 151/1997 y $162 / 2008)$.

Como acertadamente apunta Bueno Armijo (2010b), «no basta con que un comportamiento sea censurable o con que suponga una vulneración abierta de una prohibición para que sea constitutivo de una infracción administrativa». La ilicitud de la conducta será «necesaria, pero no suficiente» para que esta sea considerada infracción (p. 162). En efecto, como explica el Tribunal Supremo, «no siempre la eficacia coercitiva de un mandato incumplido o de una prohibición no respetada determina una infracción sancionable, [puesto que, en ocasiones, dicha sanción puede ser] sustituida bien por

43. En este mismo sentido estaba redactado el artículo 24 del Código Penal de 1973. De acuerdo con este, el Tribunal Supremo, en la sentencia 692/1997 FJ 248, permitió la posibilidad de aplicar retroactivamente a unos funcionarios públicos la redacción dada al delito de cohecho (CPen, 1973, art. 390) tras la reforma realizada por la Ley Orgánica 9/1991, de 22 de marzo que modificaba dicho artículo alterando la naturaleza de la pena. La redacción anterior a dicha reforma castigaba este delito con la suspensión de empleo público y con multa de 30.000 a 150.000 pesetas; mientras que la redacción posterior imponía la pena de arresto mayor y multa del tanto al triplo del valor de la dádiva o regalo, sin que pudiera ser inferior a 100.000 pesetas. En este caso, el Tribunal falló que para fijar la norma sancionadora más favorable y, en su caso, aplicar su retroactividad, debía oírse al reo, dada la diferente naturaleza Tribunal fallo que para fijar la norma sancionadora mas favorable y, en su caso, aplicar su retroactividad, debia oirse al reo, dada la diferente naturaleza
de la pena.

44. El mismo principio puede encontrarse también en el ordenamiento jurídico colombiano, en el artículo 14 del Código Disciplinario Único - Ley 734 de 2002 ( «Favorabilidad. En materia disciplinaria la ley permisiva o favorable, aun cuando sea posterior, se aplicará de preferencia a la restrictiva o desfavorable. Este principio rige también para quien esté cumpliendo la sanción, salvo lo dispuesto en la Carta Política») y en el artículo 8 del nuevo Código General Disciplinario - Ley 1952 de 2019.

45. En este sentido, el Tribunal Constitucional afirma que «la garantía material de lex certa integra el derecho a no ser sancionado en aplicación de una disposición imprecisa» (sentencia 283/2006). 
una ejecución forzosa o por la inoperancia de lo realizado en contra de la prohibición» (Tribunal Supremo, sentencia de 15 de febrero de 1999, FJ 2) ${ }^{46}$. De esta forma, y ya refiriéndonos al ámbito que nos compete, el mero incumplimiento por parte de un empleado público de alguno de los deberes que le son propios no es suficiente para imponerle una sanción, sea penal o administrativa, sino que es necesaria, en todo caso, una norma en la que se tipifique dicho incumplimiento como delito o infracción y se indique el castigo que le puede corresponder.

Lo dicho no empece para admitir descripciones de infracciones más o menos amplias o, incluso, no tan precisas como parecería en principio exigible por la garantía de taxatividad. En efecto, no es posible abstraerse de la realidad. En muchas ocasiones, el comportamiento humano es incierto y poco predecible y sería desproporcionado exigirle al legislador que precisase con absoluta exactitud los comportamientos que considera dignos de sanción. Consciente de esto, el Tribunal Constitucional aclaró desde temprano que «la exigencia de lex certa -incorporada más específicamente en el art. 25.1 CE que en el 9.3 CE-, garantía de certidumbre o seguridad jurídica, se mueve dentro de límites humanos; la claridad y precisión absolutas son inalcanzables, y los lenguajes naturales siempre dejan un margen de indeterminación» (Tribunal Constitucional, sentencia 62/1982, FJ 7). En este sentido, el uso de los conceptos jurídicos indeterminados es común y ampliamente aceptado. La utilización de estos por el legislador no es incompatible con el principio de taxatividad, siempre y cuando, «su concreción sea razonablemente factible en virtud de criterios lógicos, técnicos o de experiencia, y permitan prever (...), con suficiente seguridad, la naturaleza y características esenciales de las conductas constitutivas de la infracción tipificada» (Tribunal Constitucional, sentencia 150/1991, FJ 5) ${ }^{47}$. Así, la inclusión de conceptos jurídicos indeterminados desplazará la atención al principio de tipicidad en sentido estricto y a los aplicadores del Derecho para valorar si se vulnera o no el

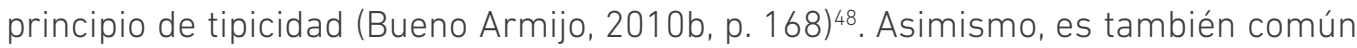
la existencia de normas sancionadoras en blanco, esto es, normas que se remiten a otras normas bien de rango legal o bien reglamentario para completar la descripción de la conducta infractora ${ }^{49}$. En lo que respecta a la tipicidad, estas normas, en principio, no vulneran el principio de legalidad aun cuando se necesiten más de una norma para la comprensión completa del tipo sancionador ${ }^{50}$.

Todo lo dicho, sin embargo, debe matizarse cuando se trate de su aplicación a infracciones disciplinarias, como veremos más adelante.

\section{b) Principio de tipicidad en sentido estricto}

En definitiva, lo que trata de garantizar el principio de tipicidad es que no se impongan penas o sanciones sorpresivas, sino que estas sean consecuencia lógica de la comparación entre la conducta realizada y la descrita en el tipo de la norma sancionadora. Por tal motivo, no es suficiente por sí misma la taxatividad de la norma para considerarse respetado el principio de tipicidad y, en última instancia, el principio de seguridad jurídica. Como formula Gallardo Castillo (2015), la seguridad jurídica es, también, «la confianza o 46. En la misma se citan las SSTS de 29 de enero de 1992 y de 28 de abril de 1998.

47. Esta sentencia reproduce el sentido de lo ya dicho en su sentencia 69/1989. FJ 1

48. Siguiendo los ejemplos propuestos por este mismo autor, puede señalarse la infracción tipificada como falta grave en el art. 7.1.e) RDD, «la grave desconsideración con los superiores, compañeros o subordinados», en la que se utiliza un concepto jurídico indeterminado, «grave desconsideración», con el fin de recoger conjuntamente en un solo tipo muchas conductas que podrían ir por separado («insultar», «vejar», «humillar», etc.) y evitar que quede sin tipificar, por error, alguna de ellas. Por ejemplo, es difícil que el legislador hubiera pensado en tipificar expresamente conductas como lanzar esputos a pantalón de un superior, a las paredes, las moquetas o las sillas o arrojar agua sobre las sillas de los ordenanzas, conductas todas ellas que se entienden incluidas dentro del concepto jurídico indeterminado «grave desconsideración» (Audiencia Nacional, sentencia de 11 de febrero de 2013). Otros ejemplos de conceptos jurídicos indeterminados pueden ser el de «abandono del servicio» o el de «notoria falta de rendimiento», utilizados en algunas faltas leves tipificadas en el artículo 6 RRD.

49. Estas normas «representan un instrumento necesario para evitar la petrificación o anquilosamiento de la ley» en los casos en que la materia objeto de regulación es extraordinariamente cambiante (v. gr., urbanismo, medio ambiente, etc.) (Abel Souto, 2005, pp. 20-21).

50. El problema surge cuando la remisión se produce a un conjunto de disposiciones heterogéneas y de tan diversa procedencia que dificulten en tal grado la comprensión del tipo que haga impredecible su aplicación. Un análisis en torno a los problemas de este tipo de normas y su compatibilidad con los principios de tipicidad y reserva de ley pueden verse en Zúñiga Morales (2004, pp. 161-182, en especial para el caso español, pp. 167-171). 
la expectativa razonablemente fundada de los ciudadanos en cuál será la actuación de los poderes públicos en la aplicación del Derecho» (p. 56) $)^{51}$. Sobre esta base, «ha de rechazarse cualquier tipo de interpretación extensiva, analógica o inductiva» (Tribunal Supremo, sentencia de 3 de abril de 2000, FJ 2), que haga difícilmente previsible la eventual sanción, en nuestro caso, para el empleado público ${ }^{52}$.

Como exigencia derivada de esta vertiente del principio de tipicidad, resulta imperiosa la motivación concreta y en detalle sobre la subsunción de los hechos sancionados en el tipo, penal o administrativo, en que se basa dicho castigo (Sánchez Morón, 2018, p. 343).

\section{c) Principio de reserva de ley}

El principio de reserva de ley, como ya hemos adelantado, representa la garantía formal del principio de legalidad contenido en el artículo 25.1 CE, por el cual las infracciones -penales o administrativas- y las sanciones que resulten aplicables deben estar contenidas en la «legislación» vigente. El término «legislación» ha sido interpretado por el Tribunal Constitucional (sentencias 42/1987, 3/1988, 101/1988, $83 / 1980,132 / 2001,144 / 2011$ y la ya citada 13/2013, entre otras), la jurisprudencia [Tribunal Supremo, sentencias de 30 de marzo 2001 y de 26 de junio de 2001, entre otras] y buena parte de la doctrina científica (véase Cosculluela Montaner, 2016. pp. 623-624; y Parada Vázquez y Fuentetaja Pastor, 2017, p. 472)53 en el sentido de requerirse una norma con rango legal que tipifique los ilícitos, tanto penales como administrativos, y establezca las correspondientes penas y sanciones. Dicho de otra forma: se trata de un ámbito reservado al legislador (de ahí su nombre) y vedado a la regulación mediante normas reglamentarias, es decir, normas aprobadas por la Administración. El fundamento de esta exigencia radica en la separación de poderes y en la proclamación del Parlamento como la institución que representa a los ciudadanos, titulares de la soberanía del Estado. El Parlamento, a través de las leyes que aprueba, es la única institución legitimada para limitar la libertad y la propiedad de los ciudadanos (Bueno Armijo, 2010a, pp. 115-116). Por consiguiente, en tanto que la tipificación de delitos o infracciones administrativas supone la represión de ciertas conductas y dado que las sanciones implican, por definición, una reducción de la libertad ${ }^{54}$ del individuo o una afectación a su propiedad ${ }^{55}$, las normas con rango legal son las únicas válidas para llevar a cabo esta función de tipificación de ilícitos y sanciones ${ }^{56}$. No obstante, lo dicho no impide, como más adelante se estudiará, una cierta colaboración reglamentaria que complete y concrete los extremos donde no ha llegado el legislador.

51. Este mandato en la aplicación del Derecho adquiere una notable importancia si se tiene en cuenta la frontera «en mayor o menor medida, ineludiblemente borrosa» entre las conductas que deben entrar dentro del tipo y aquellas que quedan fuera (Tribunal Constitucional, sentencias 120/1996, FJ 8; y 133/1990, FJ 2)

52. En esta línea se pronuncia la STC 9/2006, FJ 4. En dicho caso, el TC anuló la sanción que se había impuesto al empleado de un Ayuntamiento por un escrito dirigido al Alcalde en el que se ponían de manifiesto discrepancias, únicamente de carácter técnico, con el Interventor Local. El TC rechazó que dicha conducta pudiera incardinarse en la infracción disciplinaria consistente en «la falta de consideración hacia los administrados o hacia el personal al servicio de la Administración en el ejercicio de sus funciones». A juicio del TC, calificar la discrepancia técnica que había expresado el empleado del Ayuntamiento como «falta de consideración» suponía una interpretación imprevisible del tipo y, por tanto, contraria al principio de tipicidad.

53. En contra de que el principio de reserva de ley sea exigible en el ámbito administrativo sancionador puede verse Nieto García (2012, pp. 170 y siguientes). 54. Paradigmáticas son, en el orden penal, las penas de prisión, privativas de libertad; medidas proscritas en el orden administrativo sancionador civil, pero no así otras que igualmente reducen el ámbito de libertad del sancionado. En concreto, en el ámbito disciplinario del empleado público, pueden mencionarse las sanciones que consisten en el traslado forzoso del empleado con cambio de localidad de residencia o la inhabilitación para empleo o cargo público, sanción también prevista en el orden penal.

55. Igualmente paradigmáticas resultan en este caso las sanciones de multa, comunes en el Derecho Penal y el Derecho Administrativo Sancionador. Para el caso específico del ámbito disciplinario de los empleados públicos españoles, en el que no está prevista la sanción administrativa de multa (a diferencia de lo que acontece en Colombia: artículo 44.4 del Código Disciplinario Único - Ley 734 de 2002; artículos 48.6 y .7 del Código General Disciplinario - Ley 1952 de 2019), pueden señalarse como sanciones que afecten a la propiedad del sancionado la suspensión de empleo y sueldo por un periodo de tiempo determinado.

56. A este respecto, se debe advertir de que el principio de reserva de ley no se aplica igual a los funcionarios y al personal laboral en tanto que, como ya se analizó, la tipificación de las faltas de estos últimos, junto con su correspondiente sanción, se lleva a cabo por medio de los Convenios Colectivos, que no son norma de rango legal, ni siquiera reglamentario, sino pactos de contenido laboral entre la Administración y sus empleados. 
d) El principio de legalidad y la condición de empleado público. La relajación de los principios de tipicidad y reserva de ley

Las relaciones especiales de sujeción y, paradigmáticamente, las del empleado público, generan toda una serie de derechos y deberes que sitúan a este en una posición especial frente a la Administración. Esta posición modula, a su vez, algunos principios del ordenamiento jurídico, entre los que se incluye el principio de legalidad en sus vertientes de principio de tipicidad y de reserva de ley.

\section{a) La relajación del principio de tipicidad: el deber de saber}

El deber de saber demandado a los empleados públicos, derivado del hecho de que se encuentran en una relación de sujeción especial con la Administración, exige una interpretación más flexible del principio de tipicidad, lo que ocurre en las dos vertientes de este principio. En efecto, según ha entendido la jurisprudencia, «el artículo 25.1 CE tiene un alcance diferente, al menos, en lo que se refiere a la tipificación del ilícito, cuando se trata de la determinación de contravenciones (faltas) en el seno de una relación de sujeción especial» (Tribunal Supremo, sentencia de 22 de julio de 2000, FJ 2).

Este alcance «diferente» del principio de tipicidad tiene su base en que «la naturaleza o el contenido jurídico de la relación [de sujeción especial] permite una más fácil predicción de aquellas conductas y sanciones», con mayor lógica cuando se trate de empleados públicos, que se insertan físicamente y de manera duradera en la Administración y a quienes se les exige un especial conocimiento de la normativa relativa a sus funciones ${ }^{57}$.

Este razonamiento se puede ver plasmado con mayor o menor dificultad en muchos de los tipos penales y disciplinarios relativos a los empleados públicos, cuya vaguedad descriptiva haría imposible, para cualquiera que no fuera un empleado público, prever y conocer, con un mínimo grado de certeza, qué conductas podrían ser objeto de sanción. El paradigma de esta laxitud en el ámbito disciplinario es, posiblemente, la infracción tipificada por el artículo 8.e) TREBEP, consistente en «el incumplimiento de los deberes y obligaciones del funcionario, siempre que no deban ser calificados como falta muy grave o grave».

No obstante lo dicho, esta aplicación, más laxa, no puede suponer en ningún caso el quebranto del fundamento último del principio de tipicidad, que es la previsibilidad de las conductas sancionables y sus consecuencias, esto es, la seguridad jurídica. En este sentido, explica el Tribunal Supremo, «la obligada prevalencia (...) del principio de seguridad jurídica sobre el de eficacia de la organización administrativa y de los servicios públicos, impide que la exigencia más suave del mandato de tipificación en dichas resoluciones pueda rebasar el límite tras el cual la certeza no fuera alcanzable ni tan siquiera para quienes forman parte de ella» (Tribunal Supremo, sentencia de 1 de febrero de 1999, FJ 4). En definitiva, dada la relajación del principio de taxatividad, que una sanción sea conforme al principio de tipicidad dependerá de que el órgano sancionador interprete de forma razonable y predecible la norma sancionadora, es decir, que sea respetuoso con el principio de tipicidad en sentido estricto (Marina Jalvo, 2015, pp. 67-68) ${ }^{58}$.

57. En este sentido, tanto el Tribunal Supremo (sentencias de 6 de marzo de 2006, FJ 6, y de 10 de octubre de 2006, FJ 2) como el Tribunal Constitucional (sentencias 151/1997, FJ 3) entienden que los empleados públicos (en los casos juzgados, militares) «tienen un conocimiento específico de las pautas de conducta que, por estimarse ilegítimas, se hallan prohibidas por el ordenamiento y pueden, por consiguiente, ser sometidas a sanción».

58. De acuerdo con esto, el Tribunal Supremo (sentencia de 1 de febrero de 1999) estimó el recurso de casación de un Guardia Civil que había sido sancionado disciplinariamente por la falta grave de «observar conductas gravemente contrarias al servicio o dignidad de la Institución cuando no constituyan delito». Este Guardia Civil, al encontrarse el coche abandonado de un familiar de un Oficial de la Guardia Civil retirado, realizó unas actuaciones tendentes a hacer creer que el coche había sido robado y que, en definitiva, había sufrido una serie de daños. El Tribunal entendió que la subsunción de estos hechos 
b) La relajación del principio de reserva de ley. En especial, el Reglamento de Régimen Disciplinario de los Funcionarios de la Administración del Estado (RRD)

Al igual que ocurre con el principio de tipicidad, el principio de reserva de ley también sufre de una gran relajación cuando se trata de relaciones especiales de sujeción y, en especial, la que vincula a los empleados públicos. De esta forma, el papel que se reconoce a las normas de contenido sancionador aprobadas por la Administración va mucho más allá de la mera «colaboración reglamentaria».

En efecto, como se evidencia de la jurisprudencia, la existencia de una relación especial de sujeción también lleva a reducir al mínimo las exigencias derivadas del principio de reserva de ley. Como expone el Tribunal Supremo, «tratándose de relaciones especiales de sujeción, basta con la existencia de una habilitación en una norma con rango legal y no se requiere en este ámbito contenido material alguno». Y esto porque «el ius puniendi no es el genérico del Estado, y en tal medida la propia reserva de ley pierde parte de su fundamentación material, dado el carácter insuprimible de la potestad reglamentaria, expresiva de la capacidad propia de autoordenación para determinar en concreto las previsiones legislativas abstractas sobre las conductas identificables como antijurídicas» (sentencia de 16 de marzo de 2001, FJ 3) ) $^{59}$

Buen ejemplo de todo ello es lo ocurrido con los artículos 7 y 8 RDD. Desde 1986, estos preceptos tipificaban las faltas disciplinarias graves y leves de los funcionarios de la Administración General del Estado, gracias a la cobertura legal que les ofrecía el artículo 89 de la Ley de Funcionarios Civiles del Estado, aprobada por Decreto 315/1964, de 7 de febrero (en adelante, LFCE).

La disposición derogatoria del TREBEP derogó expresamente el artículo 89 LFCE, sin hacer referencia alguna a la situación en la que se dejaba a los artículos 7 y 8 RRD. Ello generó serias dudas, no solo entre la doctrina científica (véase Parada Vázquez y Fuentetaja Pastor, 2017, pp. 473-474), sino también entre la jurisprudencia menor ${ }^{60}$, sobre la existencia de cobertura legal suficiente del RRD y, por tanto, sobre su vigencia, al entender que podría haberse convertido en una norma reglamentaria que ya no completaba ninguna ley sancionadora, sino que establecía, por sí misma, todo un régimen sancionador, en abierta vulneración del principio de reserva de ley.

Esta cuestión fue resuelta finalmente por el Tribunal Supremo (sentencia 548/2017, de 30 de marzo) quien falló declarando conforme al principio de reserva de ley el mantenimiento de la tipificación de las faltas graves y leves realizada por los artículos 7 y 8 RRD. Esta decisión se motivó principalmente sobre dos argumentos. Por un lado, se estimó que la falta de una habilitación legal expresa del RRD se debía a «una descuidada técnica legislativa» y no al deseo del legislador de derogarlo. Por otro lado, se consideró que la cobertura legal del mismo se infiere de la Disposición adicional cuarta del TREBEP que mantiene en vigor «las normas vigentes» sobre «ordenación, planificación y gestión de recursos humanos»-materias en las que el Tribunal Supremo entendió incluido el régimen disciplinario-, en cuanto no se opongan a lo establecido en el TREBEP y hasta tanto se aprueben las Leyes de Función Pública y sus normas reglamentarias de desarrollo.

en el tipo sancionador no era razonable ni previsible.

59. Reproduce parcialmente lo dicho por el Tribunal Constitucional en la sentencia 2/ 1987, FJ 2. Ello, sin embargo, es referido al orden administrativo sancionador y no al orden penal, donde la exigencia de este principio es mucho más rigurosa, manteniendo el reglamento una colaboración más modesta en la tipificación de las infracciones. Véase el artículo 441 CPen que prohíbe la realización de actividades privadas por empleados públicos ufuera de los casos admitidos en las leyes o reglamentos». En este caso, el Reglamento ni siquiera concreta las conductas prohibidas, sino por el contrario las permitidas. 60. Fue el caso de la SJCA de Sevilla de 28 de mayo de 2015, en la que el Tribunal entendió derogados los artículos 7 y 8 RDD. 
Esta solución dada por el Tribunal Supremo, que no sería posible si no estuviéramos ante relaciones especiales de sujeción, es sin duda la más pragmática, pues la derogación de los artículos 7 y 8 RRD hubiese supuesto la imposibilidad de la Administración de corregir las conductas subsumibles en los referidos artículos respecto a un gran número de funcionarios ${ }^{61}$. Sin embargo, sigue resultando un tanto discutible esta solución por la forzada interpretación de los preceptos que el Tribunal llevó a cabo y por la práctica desaparición del principio de reserva de ley que conlleva.

\subsubsection{Principio de antijuricidad}

La antijuricidad es el segundo elemento que forma parte del supra-concepto de ilícito al que nos referimos al comienzo de este epígrafe. Tal vez sea el elemento sobre el que menos ha centrado su atención la doctrina y, en cierto sentido, es lógico pues la Constitución Española no hace mención expresa a este principio, al igual que ocurre en la legislación ordinaria. Su construcción surge de la lectura contrario sensu del artículo $20.4^{\circ}, 5^{\circ}$ y $7^{\circ} \mathrm{CPen}$, con su posterior traslación al Derecho Administrativo Sancionador ${ }^{62}$.

a) El fundamento de la antijuricidad como elemento de la infracción

La existencia de este principio se explica por la misma lógica del ius puniendi del Estado. Este tiene por misión reprimir conductas concretas, mediante la tipificación de delitos e infracciones administrativas, cuyo fin último es el de garantizar la indemnidad de los bienes jurídicos que el legislador considera dignos de protección. Como explica Bueno Armijo (2010d), el daño que pueda causársele al bien jurídico protegido es lo que se identifica con la antijuricidad (p. 222). En esta lógica, ante la falta de daño alguno no hay, en principio, conducta reprochable y por lo tanto infracción cometida. En definitiva, no es suficiente pues, la realización de la conducta tipificada, sino que es necesario que dicha conducta produzca una lesión efectiva al bien jurídico que el legislador pretende proteger en la norma sancionadora. Todo esto implica, trasladado al ámbito que nos ocupa, que únicamente serán sancionables disciplinariamente aquellas conductas que afecten a alguno de los bienes jurídicos protegidos a los que hicimos referencia al comienzo de este epígrafe y, muy especialmente, la Administración pública, sus bienes, su imagen y su correcto funcionamiento, concretado con frecuencia en la observancia de los principios de objetividad y eficacia (CE, 1978, art. 103.1).

b) Los delitos e infracciones de mera actividad, de peligro o formales

A lo dicho anteriormente, sin embargo, hemos de añadir que, junto al daño efectivo también se viene aceptando como antijurídica la acción u omisión que simplemente ponga en riesgo el bien jurídico protegido. Se trata de reprimir no solo las conductas que generan un daño en el bien jurídico, sino también aquellas que por sus características sean idóneas para producir tal daño y, por tanto, ponen en peligro el bien jurídico. Se habla entonces de delitos e infracciones de peligro o de mera actividad, puesto que lo que se le recrimina al sancionado es precisamente la puesta en peligro del bien jurídico, lo que no requiere pues resultado alguno, esto es, daño real, sino la mera actividad -o inactividad-que propicia dicho riesgo. También son conocidas como infracciones formales, en tanto son producto normalmente del incumplimiento de una obligación formal.

61. Recuérdese que, a falta de la aprobación de las Leyes de Función Pública de las Comunidades Autónomas, el RRD es de aplicación también a los funcionarios públicos de aquellas, debido al carácter supletorio de la normativa estatal (CE, 1978, art. 149.3).

62. No es este el caso del ordenamiento jurídico colombiano, en el que la exigencia de antijuridicidad o ilicitud sustancial se prevé expresamente en el artículo 5 del Código Disciplinario Único - Ley 734 de 2002, conforme al cual «La falta será antijurídica cuando afecte el deber funcional sin justificación alguna». El artículo 9 del Código General Disciplinario - Ley 1952 de 2019 mantiene esta misma exigencia, aunque ya no utiliza el término «antijuridicidad» y elimina las referencias a la posible existencia de causas de justificación. 
Aunque este tipo de infracciones son mucho más numerosas en su vertiente administrativa, no son raras en el Derecho Penal. Un claro ejemplo sería el delito de cohecho impropio (CPen, 1995, art. 422) por el que se condena al empleado público que «en provecho propio o de un tercero, admitiera, por sí o por persona interpuesta, dádiva o regalo que le fueren ofrecidos en consideración a su cargo o función». Basta entonces con la simple aceptación de la dádiva para entender lesionado el bien jurídico protegido (Tribunal Supremo, sentencia 636/2006, FJ 1)63. Por su parte, en el orden administrativo sancionador, en concreto, en el ámbito disciplinario, podemos encontrar entre otros ejemplos la falta consistente en «intervenir en un procedimiento administrativo cuando se dé alguna de las causas de abstención legalmente señaladas» [art. 7.1.g) RDD] ${ }^{64}$.

El problema de este tipo de infracciones en las que no se exige resultado es que la apreciación de la falta de antijuricidad, es decir, de esa falta de puesta en peligro, resulta harto complicada toda vez que la puesta en riesgo del bien jurídico protegido se presume producida con la simple comisión de la conducta tipificada (Tribunal Superior de Justicia de Madrid, sentencia 818/2002, FJ 8] ${ }^{65}$. Con todo y con esto, existen pronunciamientos en los que se ha apreciado la falta de antijuricidad en este tipo de infracciones ${ }^{66}$.

\section{c) Las causas de justificación. En especial. El cumplimiento de un deber}

Cuestión distinta es el caso en el que efectivamente se produce un daño al bien jurídico protegido por la norma sancionadora, pero dicha lesión no se considera antijurídica, es decir, no es una lesión contraria al ordenamiento jurídico, sino amparada por este. Esto tiene su explicación en la concurrencia de otro bien jurídico que merece igual o mayor protección. En estos casos, el daño causado al bien jurídico perjudicado está justificado por la salvaguarda de otro bien jurídico protegido. Hablamos en estos casos de «causas de justificación». El Código Penal establece como causas de justificación la legítima defensa (CPen, 1995, art. 20.4º67, el estado de necesidad (CPen, 1995, art. 20.5) y el ejercicio legítimo de un derecho, oficio o cargo o el cumplimiento de un deber (CPen, 1995, art. 20.7%). Causas que se han trasladado igualmente al orden administrativo sancionador ${ }^{68}$, en el que la jurisprudencia ya ha admitido al menos dos de ellas: el estado de necesidad ${ }^{69}$ y el ejercicio legítimo de un derecho, oficio o cargo, o el cumplimiento de un deber.

Para la responsabilidad del empleado público resulta de especial interés la tercera causa de justificación: el ejercicio legítimo de un derecho, oficio o cargo, y, en particular, el cumplimiento de un deber.

Respecto al ejercicio legítimo de un derecho, han sido varios los pronunciamientos judiciales, en particular, en el orden administrativo, que han apreciado esta causa de justificación en el ejercicio de derechos fundamentales, como el derecho a la salud,

63. También se han calificado por la jurisprudencia como delitos de mera actividad, entre otros, los delitos de fraude (CPen, 1995, art. 436) [Tribunal Supremo, sentencia 257/2019, FJ 3] o el de intervención en actividades prohibidas (CPen, 1995, art. 439) [Tribunal Supremo, sentencia 163/2019, FJ 32], todos ellos previstos para empleados públicos.

64. En este supuesto de conflicto de intereses, que podría venir constituido, por ejemplo, por la participación de un empleado público en un asunto en el que tuviere interés particular directo su cónyuge, no se exige que el empleado haya beneficiado indebidamente al cónyuge: su mera participación, y el riesgo para la objetividad e imparcialidad de la Administración que ello conlleva, es suficiente para entender que la conducta es antijurídica. Cfr., artículos 40, 50 y 84 del Código Disciplinario Único - Ley 734 de 2002, para el caso de Colombia.

65. Especialmente criticados son, en el Derecho Penal, los delitos de peligro abstracto, en los que se entiende que este peligro existe independientemente de que se haya creado efectivamente un riesgo. A este respecto, véase Méndez Rodríguez (1993, pp. 193 y siguientes).

66. Es el caso de la STS de 4 de junio de 2004, en la que un Guardia Civil había sido sancionado disciplinariamente por «la falta de colaboración manifiesta con los demás miembros de las Fuerzas y Cuerpos de Seguridad», al no haber denunciado la situación administrativa irregular de su compañera sentimental de nacionalidad brasileña. Sin embargo, el Tribunal entendió que la falta de denuncia no puso en peligro bien jurídico alguno, en tanto que las Fuerzas y Cuerpos de Seguridad ya conocían de la situación administrativa irregular de la pareja sentimental del Guardia Civil y, de hecho, ya se estaba tramitando el expediente de expulsión contra la misma.

67. Es el caso de la STS 1053/2002, en el que un policía disparo al muslo a una persona que se abalanzó sobre él blandiendo un cuchillo de grandes dimensiones. El Tribunal entendió que efectivamente actuó en legítima defensa.

68. Como acertadamente afirma Castillo Blanco (1992, pp. 329-332), la no previsión de causas de justificación [con carácter general] en el régimen disciplinario no empece su vigencia respecto a este.

69. No obstante, los pronunciamientos en el orden administrativo sancionador en los que se ha admitido esta causa de justificación son escasos. Véase a este respecto a Bueno Armijo (2010d, pp. 228 y siguientes). 
a la asociación o a la libertad de expresión, entre otros. De esta forma, algunas conductas que implicaban el ejercicio de estos derechos no han podido ser objeto de sanción disciplinaria aun siendo típicas, es decir, aun siendo constitutivas de un tipo disciplinario (Cfr. Bueno Armijo, 2010d, pp. 234-248)70.

En cuanto al cumplimiento de un deber, tal vez sea la causa de justificación que más se aprecia tanto en el orden penal como administrativo en relación con la exigencia de responsabilidad disciplinaria a los empleados públicos. Un ejemplo es el caso de desobediencia por parte del empleado público de un mandato u orden por una autoridad o superior jerárquico cuando este resulte manifiestamente contrario al ordenamiento jurídico; causa de justificación recogida por el legislador tanto en el ámbito penal (CPen, 1995, art. 410; y CP Militar, 2015, art. 44.3) como en el disciplinario [TREBEP, 2015, art. 95.2 i); y LORDGC, 2007, art. 7.5]. El respeto a la Constitución y al ordenamiento jurídico (TREBEP, 2015, arts. 52 y 53.1) no solo justifica, sino que exige la desobediencia de dichas órdenes. Tal desobediencia no constituye solo una causa de justificación, sino un deber del empleado público [Tribunal Supremo, sentencia 32/2018, FJ 2] $]^{71}$.

\subsubsection{Principio de culpabilidad}

El tercer elemento que completa la definición del supra-concepto de ilícito es el de la culpabilidad. A pesar de su falta de proclamación expresa, se acepta unánimemente la consagración de este principio por la Constitución Española, «como exigencia derivada del artículo 25.1 CE, según la cual nadie puede ser condenado o sancionado sino por hechos que le puedan ser imputados a título de dolo o culpa» [Tribunal Supremo, sentencia de 19 de mayo de 1998, FJ 2] $]^{72}$ y como consecuencia lógica de la presunción de inocencia consagrada en el artículo 24.2 CE [Tribunal Constitucional, sentencia 76/1990, FJ 8 B)]. Por tanto, dice el Tribunal Supremo, «no basta con que la conducta sea antijurídica y típica, sino que también es necesario que sea culpable, esto es, consecuencia de una acción u omisión imputable a su autor por malicia o imprudencia, negligencia o ignorancia excusable» [Tribunal Supremo, sentencia de 12 de mayo de 1998, FJ 2; y de 19 de mayo de 1998, FJ 2].

Así lo entendió el legislador, que estableció claramente, en el orden penal, que «no hay pena sin dolo o imprudencia» (CPen, 1995, art. 5) y, en el orden administrativo sancionador, que «solo podrán ser sancionadas por hechos constitutivos de infra- cción administrativa las personas (...) que resulten responsables de los mismos a título de dolo o culpa» (LRJSP, 2015, art. 28.1). También en el ámbito disciplinario de los empleados públicos se establece, de manera más lacónica, que «la potestad disciplinaria se ejercerá de acuerdo con el principio de culpabilidad» [TREBEP, 2015, art. 94.2 d)] ${ }^{73}$.

Como sintetiza Bueno Armijo (2018a), la consagración de este principio lleva consigo, al menos, tres consecuencias: a) el principio de personalidad de la sanción; b) la exigencia de dolo o culpa; y c) la prohibición de sanción cuando concurra una causa de exclusión de la culpabilidad (p. 261)74.

70. El que se trate de derechos fundamentales implica un plus en la protección de estos, lo que explica que, en muchas ocasiones, el ejercicio de estos prevalezca sobre algunos de los deberes del empleado público. No obstante, la especial protección de los derechos fundamentales no empece para que estos también sufran limitaciones en pro del buen funcionamiento de la Administración acorde con los principios del artículo $103.1 \mathrm{CE}$. Un estudio de estas limitaciones se puede ver en López Benítez (1994, pp. 445-569).

71. A este respecto, véase Hernández Suárez-Llanos, (2010, pp. 145-170). Otros ejemplos ilustrativos son los aportados por Gómez Tomillo y Sanz Rubiales (2017): «el policía que infringe las normas de seguridad vial para perseguir y detener a un delincuente en fuga (...) o el conductor de una ambulancia profesional que traslada a un paciente a un centro hospitalario sin respetar preferencias de paso» (p. 426).

72. Igualmente, el Tribunal Constitucional ha ratificado su consagración como principio constitucional, tanto en el orden penal (sentencia 150/1991, FJ 4), como en el orden administrativo sancionador «en la medida en que la sanción de dicha infracción es una de las manifestaciones del ius puniendi de Estado» (sentencia 246/1991, FJ 2).

73. Aún más rotundo se ha mostrado el legislador colombiano, que ha establecido que «en materia disciplinaria queda proscrita toda forma de responsabilidad objetiva. Las faltas sólo son sancionables a título de dolo o culpa», artículo 13 del Código Disciplinario Único - Ley 734 de 2002 y, en términos muy similares, el nuevo artículo 10 del Código General Disciplinario - Ley 1952 de 2019.

74. Un estudio en detalle de todos estos extremos puede encontrarse en Izquierdo Carrasco (2010, pp. 249-357) 
a) El principio de personalidad de la sanción. Los sujetos responsables

El principio de personalidad de la sanción puede extraerse, sin mayores problemas, del propio artículo 25.1 CE, el cual establece que «nadie puede ser condenado o sancionado por acciones $u$ omisiones que en el momento de producirse no constituyan delito, falta o infracción administrativa». Es decir, una persona solo podrá ser condenada o sancionada por acciones u omisiones propias, sin que se le pueda pedir responsabilidad sancionadora directa ni subsidiaria por las conductas que otras personas puedan realizar (véase Baca Oneto, 2019, pp. 319-323).

Ello conlleva que el responsable del delito o infracción cometidos deba ser el autor de estos. Sin embargo, lo anterior no obsta a que se pueda sancionar a otros sujetos que, con su propia conducta, colaboren en el delito o infracción de otro (Rebollo Puig e Izquierdo Carrasco, 2018, p. 213) ${ }^{75}$.

En línea con esto, el Código Penal califica como responsables criminalmente a los autores y cómplices (CPen, 1995, art. 27), siendo estos el inductor, el cooperador necesario, así como cualquier otro que coopere en la ejecución del hecho (CPen, 1995, arts. 28 y 29). Por su parte, el Derecho Administrativo Sancionador no prevé, con carácter general, la posibilidad de sancionar a los partícipes en la infracción distintos del infractor principal. Sin embargo, como peculiaridad del régimen disciplinario, sí se establece en este ámbito como responsables de las infracciones disciplinarias a los empleados públicos que indujeren o encubrieren las faltas disciplinarias de otros (TREBEP, 2015, art. 93.2 y 3$)^{76}$.

El castigo correspondiente a estos partícipes dependerá de la forma en la que se haya participado en el delito o infracción disciplinaria. El inductor será considerado a estos efectos como autor del delito o la falta disciplinaria que hubiese alentado, por lo que le corresponderá la misma sanción -penal o administrativa- que al autor principal de los hechos [CPen, 1995, art. 28.a); y TREBEP, 2015, art. 93.2]. En cambio, se produce un tratamiento diferenciado entre el Derecho Penal y el régimen disciplinario en cuanto a la figura del encubridor. El Derecho Penal tipifica esta conducta de manera -digamos- autónoma, con la pena de seis meses a tres años de prisión (CPen, 1995, art. 451) ${ }^{77}$ y con el límite - por otro lado, lógico- de que esta pena de prisión no supere la señalada al delito encubierto (CPen, 1995, art. 452). Por su parte, en el régimen disciplinario, al contrario que para el caso del inductor, nada se dice sobre la sanción que debe llevar aparejada el encubridor, de lo que se deduce que esta será más moderada que la del autor de la falta encubierta, en atención al grado de participación en la infracción (TREBEP, 2015, art. 96.3).

b) La exigencia de dolo o culpa. La responsabilidad cuasi-objetiva del empleado público y su deber de diligencia

Consagrado el principio de culpabilidad, «está vedado cualquier intento de construir una responsabilidad objetiva» (Tribunal Supremo, sentencia de 19 de mayo de 1998, FJ 2). En el caso de la responsabilidad penal, la regla general para poder castigar la comisión de un delito es que haya sido cometido dolosamente, de tal forma que solo cabe castigar la imprudencia cuando así haya sido expresamente previsto por el legislador (CPen, 1995, art. 12). En el caso de la responsabilidad administrativa sancionadora, sin embargo, la regla general es que cualquier infracción puede ser

75. Como decimos, estas personas son sancionadas por su propia conducta en la participación de la conducta antijurídica del autor principal, por lo que no se conculca con esto el principio de personalidad de la sanción.

76. En cuanto al encubrimiento, este solo será sancionado si se trata de una falta grave o muy grave.

77. Se ha de añadir, y esto es importante respecto los delitos de empleados públicos, en los que en ocasiones se contemplan solo la pena de inhabilitación de empleo público, que en el caso de que la naturaleza de la pena sea distinta a la privativa de libertad, la pena del encubridor se convertirá en una pena de multa (CPen, 1995, art. 452). 
sancionada tanto a título de dolo como de imprudencia o culpa (LRJSP, 2015, art. 28.1). También es así en el ámbito disciplinario, donde a pesar de unas primeras vacilaciones por parte de la jurisprudencia ${ }^{78}$, se ha terminado por calificar la concurrencia de dolo o culpa como «imprescindible en toda infracción disciplinaria» [Tribunal Supremo, sentencia de 25 de septiembre de 2006, FJ 7].

Ello no obstante, la formulación e interpretación jurisprudencial de algunas infracciones en el orden administrativo sancionador han llevado a afirmar a parte de la doctrina científica la existencia en el Derecho Administrativo Sancionador de una responsabilidad cuasi objetiva.

En el caso de los empleados públicos, si bien es cierto que se mantiene el principio de culpabilidad, podría pensarse que su firmeza cede en cierta forma, bastando en muchas ocasiones la existencia de una culpa levísima. Ello, en buena lógica, deriva directamente de los deberes que su condición les exige, y en particular y destacadamente, del deber de diligencia (TREBEP, 2015, art. 52), que se concreta en el "deber de saber" que tienen como profesionales que son en el ejercicio de sus funciones (Marina Jalvo, 2015, pp. 81-82) ${ }^{79}$.

No obstante, la exigencia de una diligencia cualificada por parte del empleado público no puede entenderse como una exclusión del principio de culpabilidad. A nuestro juicio, esta diligencia cualificada que se le exige al empleado público puede suponer, no tanto una responsabilidad objetiva, sino una afectación a la presunción de inocencia, la cual puede, en algunos casos, desvirtuarse con la prueba de que los hechos enjuiciados han sido efectivamente realizados por el empleado público. Según esta tesis, podría considerarse que, en ciertas ocasiones, la realización de las conductas tipificadas presupone, cuanto menos, una negligencia del empleado público; presunción que, como tal, podría ser destruida por el empleado público si se demostrase que no hubo tal negligencia. Pero ello supondría una inversión de la carga de la prueba de su inocencia y, en consecuencia, una vulneración del derecho a que esta se presuma.

c) Las causas de exclusión de la culpabilidad

Son causas de exclusión de la culpabilidad generalmente aceptadas, tanto en el Derecho Penal como en el Derecho Administrativo Sancionador, el estado de necesidad exculpante, el caso fortuito o de fuerza mayor y el error de prohibición y el error de tipo ${ }^{80}$.

En todas estas causas vuelve a tener una especial relevancia el deber de diligencia al que están sometidos los empleados públicos, que hace difícil su apreciación. Destacadamente, sobre el error de prohibición y el error de tipo ${ }^{81}$ la Audiencia Nacional es clara al afirmar que «respecto de los profesionales, difícilmente se les podrá atribuir un error invencible en cuanto al contenido y el alcance de sus funciones, y ello porque si la infracción se ha cometido por un profesional al cual, para ser tal, se le presumen ciertos conocimientos, no es posible que invoque eficazmente la ausencia de dichos conocimientos para excluir la culpabilidad» [Audiencia Nacional, sentencia de 14 de diciembre de 2006, FJ 4$]^{82}$.

78. A este respecto, la STS de 14 de julio de 1998 hace un repaso de estas primeras vacilaciones por parte de la jurisprudencia y doctrina constitucional, explicando a su vez la evolución que ha experimentado el principio de culpabilidad en el Derecho Administrativo Sancionador.

79. En este sentido se han pronunciado el Tribunal Supremo (sentencia de 17 de abril de 2002, FJ 8 y 9) y el Tribunal Superior de Justicia de Castilla y León (sentencia 266/2008, FJ 7).

80. Además, en el ámbito penal son comunes en la práctica la anomalía o alteración psíquica, la intoxicación plena por consumo de alcohol o drogas y el miedo insuperable como causas de exclusión de la culpabilidad (CPen, 1995, artículo $20.1^{\circ}, 2^{\circ}$ y $6^{\circ}$ ).

81. El error de prohibición es el que implica un desconocimiento de la tipificación de una conducta como infracción penal o administrativa, mientras el error de tipo consiste en el conocimiento de este, pero con la creencia de que la conducta realizada por el autor no cumple con todos los elementos descritos en la norma. Sobre esta causa de exclusión de la culpabilidad puede verse a Gallardo Castillo (2015, pp. 115-133).

82. En esta misma línea se pronuncian las SSTS de 9 de diciembre de 2005 y de 5 de junio de 2002. No obstante, esto no puede llevar a la eliminación de esta causa de exclusión de culpabilidad en el ámbito de la responsabilidad de los empleados públicos, más aún cuando se trata de responsabilidad penal. Precisamente, el Tribunal Supremo eximió de responsabilidad a dos empleadas de un Ayuntamiento por el delito de malversación al entender que su falta de cualificación profesional, junto a las instrucciones dirigidas por el propio Alcalde, condujeron a las acusadas a un error invencible sobre las conductas 


\subsubsection{Principio de non bis in idem}

Además del principio de legalidad, en sus diferentes vertientes, el de antijuridicidad y el de culpabilidad, el Tribunal Constitucional ha entendido incluido en el artículo 25.1 CE la garantía non bis in idem ${ }^{83}$. De manera simplificada, se suelen identificar en este principio dos vertientes: la vertiente material y la vertiente procesal ${ }^{84}$. Por un lado, nadie podrá ser sancionado dos o más veces por unos mismos hechos y sobre la base de un mismo fundamento. Se hablaría aquí de la triple identidad de sujetos, hechos y fundamentos ${ }^{85}$. Por otro lado, quedaría vedada, además, la tramitación de dos procesos punitivos sucesivos (tanto judiciales como administrativos) cuando concurra esta triple identidad ${ }^{86}$.

Por la limitada extensión de este trabajo, nos centraremos en la vertiente material de este principio. Según acabamos de indicar, en virtud de la garantía del non bis in idem no se puede imponer un doble castigo a una persona por unos mismos hechos y por un mismo fundamento. Debe añadirse ahora que este principio rige tanto para el concurso de sanciones penales, como para el concurso de sanciones administrativas y, también, para el concurso de sanciones penales y administrativas. Este tercer supuesto será especialmente frecuente en el ámbito de la responsabilidad disciplinaria ${ }^{87}$.

Lo cierto es que, en sus primeras sentencias, el Tribunal Constitucional pareció excluir la vigencia de la garantía non bis in idem cuando el concurso se producía entre sanciones penales y disciplinarias. En efecto, la ya citada STC 2/1981, proclamó la garantía non bis in idem en los casos en que se apreciara la identidad del sujeto, hecho y fundamento «sin existencia de una relación de supremacía especial de la Administración» (FJ 4), refiriéndose con ello al caso de las relaciones especiales de sujeción, como la de los empleados públicos. Sin embargo, esta aparente excepción al principio non bis in idem no era tal. El Tribunal Constitucional simplemente asumió, en un principio, que la imposición de las sanciones penales y las disciplinarias no respondían en ningún caso a un mismo fundamento y, por tanto, que nunca se podía apreciar una identidad del sujeto, hecho y fundamento, sino únicamente de los dos primeros elementos. Así lo aclaró el propio Tribunal Constitucional posteriormente, matizando que «la existencia de esta relación de sujeción especial tampoco basta por sí misma», sino que «es indispensable, además, que el interés jurídicamente protegido [de ambas sanciones] sea distinto» (Tribunal Constitucional, sentencia 234/1991, FJ 2).

enjuiciadas (STS 211/2006, FJ 7).

83. Así lo reconoció el Tribunal Constitucional en su temprana Sentencia 2/1981, de 30 de enero, FJ 4. Interpretación que se ha visto reforzada con la entrada en vigor de los artículos 50 CDFUE y 4 del Protocolo $n^{\circ} 7$ del CEDH bajo los cuales se debe interpretar el artículo 25.1 CE (ex CE, 1978, art. 10.2). Según la jurisprudencia del TEDH [sentencias de 21 de febrero de 1984 (caso Öztürk c. RFA): de 23 de octubre de 1995 (caso Gradinger c. Austria): de 29 de mayo de 2001 (caso Franz Fischer c. Austria); entre otras], el que tales preceptos aludan expresamente al orden penal, no obsta a que este principio sea igualmente aplicable a las infracciones administrativas y a su concurrencia con las penales.

84. Para un estudio jurisprudencial en profundidad de este principio véase a Alarcón Sotomayor (2010, pp. 359-422; y 2008)

85. Ese es el contenido que la doctrina constitucional y la jurisprudencia del Tribunal Supremo le han dado a la garantía del non bis in idem material desde sus comienzos hasta la actualidad (STC 2/1981, FJ 4, y STS 763/2019, FJ 5).

86. Esta vertiente queda expresamente consagrada en el artículo 50 CDFUE respecto a los enjuiciamientos penales. Dada la comunicación entre el Derecho Penal y el Derecho Administrativo Sancionador, resulta lógico pensar que esta misma garantía se debe aplicar para los procedimientos sancionadores de carácter administrativo, aunque tradicionalmente, como indica Alarcón Sotomayor (2010), «esta vertiente genuinamente procesal (...) solo rige mínimamente en el procedimiento administrativo sancionador» (pp. 359-360). Durante los últimos años, sin embargo, como ya hemos adelantado, la jurisprudencia del TEDH y del TJUE viene aplicando con total rotundidad la prohibición del doble proceso punitivo contra un mismo sujeto y unos mismos hechos, tanto en el ámbito penal como en el ámbito administrativo sancionador, lo que tal vez ha llevado a algunos excesos que sus últimos pronunciamientos han intentado matizar (Gimeno Sendra 2003, pp. 15-21: y Bueno Armijo, 2018b, pp. 951-994).

87. Como advierte Cámara del Portillo (2008), no son pocas las faltas disciplinarias y delitos que se solapan. Por citar alguno de los ejemplos que el autor menciona, se puede ver la semejanza entre la falta disciplinaria consistente en «la desobediencia abierta a las órdenes o instrucciones de un superior» [TREBEP, 2015, art. 95.1 i)] y el delito por negarse «abiertamente a dar el debido cumplimiento a resoluciones judiciales, decisiones u órdenes de la autoridad superior» (CPen, 1995, art. 410.1). Y de manera similar, la coincidencia entre la falta disciplinaria de «prevalencia de la condición de empleado público para obtener un beneficio indebido para sí o para otro» [TREBEP, 2015, art. 95.1 j)] y el delito de tráfico de influencias previsto en el artículo 428 CPen (pp. 94-95). A mayor abundamiento, esta situación debe ser. de hecho, común, si se atiende al artículo 7.1. c) TREBEP (0. en términos muy similares el artículo 8.14 LORDFAS) que tipifica como falta disciplinaria grave «las conductas constitutivas de delito doloso relacionadas con el servicio o que causen daño a la Administración o a los administrados». 
De esta forma, cabe la existencia de una doble sanción, a un mismo sujeto y en razón a unos mismos hechos si cada una de las normas sancionadoras en concurso protegen un bien jurídico distinto. En estos casos, no cabrá apreciar una vulneración del principio non bis in idem, en tanto no habrá una identidad en los fundamentos de las dos sanciones en concurrencia. Esto requiere, por tanto, el estudio caso por caso de cada concurso de sanciones, ya que tanto el Derecho Penal (CPen, 1995, Títulos XIX y XX), como el régimen disciplinario, tienen como bien jurídico protegido a la Administración y su correcto funcionamiento, la buena imagen y la correcta gestión de su patrimonio. Se hace necesario entonces, como decimos, el estudio individualizado del concurso de ilícitos para la identificación y concreción de los bienes jurídicos protegidos por cada norma sancionadora, en tanto que estas normas no suelen indicar expresamente el bien jurídico protegido (véanse Gallardo Castillo, 2015, pp. 169 y siguientes; y Rebollo Puig, 2010, pp. 423-440).

La dificultad de esta identificación es patente en la jurisprudencia, que no en pocas ocasiones ha necesitado matizar la postura previa que había mantenido. No obstante, se aprecia una línea jurisprudencial común en cuanto a la identificación de los bienes jurídicos protegidos. En primer lugar, el régimen disciplinario, sin perjuicio de la protección de otros bienes jurídicos relacionados, tiene como fin último, como ya se dijo, la salvaguarda del buen funcionamiento de la Administración pública y, como parte de él, la disciplina de las personas que en ella trabajan como empleados públicos. Además, también se identifica como bien jurídico objeto de protección la imagen de la Administración ${ }^{88}$. En consecuencia, las sanciones penales o administrativas generales que concurran con las disciplinarias deben de tener como bien jurídico protegido el funcionamiento o imagen de la Administración para entender que pudiese existir una vulneración del principio non bis in idem.

De conformidad con lo anterior, es posible identificar las líneas establecidas por el Tribunal Supremo para analizar los concursos de sanciones disciplinarias y penales. En concreto, y siguiendo el modelo propuesto por Rebollo Puig (2010b, p. 439) ${ }^{89}$, cabría distinguir las siguientes posibilidades:

«A) Si el funcionario fue condenado por delito común, no hay obstáculo alguno a la imposición de una sanción disciplinaria;

B) Si se trata de un delito especial que solo pueden cometer funcionarios, hay que distinguir:

- Si es un delito especial sin un delito común equivalente, en cuyo caso no cabe acumular la sanción disciplinaria.

- Si es un delito especial con un delito común equivalente, en cuyo caso si cabe acumular la sanción disciplinaria».

Esta sistematización parte de una premisa implícita: en los delitos que puede cometer cualquier ciudadano - delitos comunes-, el bien jurídico protegido será distinto al del buen funcionamiento e imagen pública de la Administración ${ }^{90}$. Por tanto, las sanciones

88. De hecho, como ya dijéramos, es una de las tres circunstancias que deben tenerse en cuenta para tipificar las faltas graves y leves de los empleados públicos (TREBEP, 2015, art. 95.3 y 4).

89. Este autor toma como base de esta sistematización la STS de 30 de mayo de 2000

90. Un ejemplo es el de la STS de 16 de marzo de 2004, FJ 7, en la que se había condenado a un policía como autor de un delito contra la salud pública

(CPen, 1995, art. 344) por tráfico de drogas, siendo sancionado posteriormente por la falta disciplinaria muy grave consistente en la realización de «cualquier conducta constitutiva de delito doloso» [Ley Orgánica 2/1986 de Fuerzas y Cuerpos de Seguridad, 1986, art. 27.3.b)]. Como argumentó el Tribunal, «mientras la tipificación penal protege la salud humana, la sanción administrativa lo hace en atención a la buena imagen que debe dar la institución policial en todo momento y que por un determinado comportamiento de alguno de sus integrantes no puede quedar afectada». 
disciplinarias solo serán incompatibles con las penales cuando estas deriven de un delito especial, que no tenga un equivalente como delito común ${ }^{91}$.

Con todo lo dicho, la jurisprudencia se mantiene cauta al afirmar que la «solución habrá de buscarse casuísticamente» [Tribunal Supremo, sentencia de 30 de mayo de 2000, FJ 3], lo que resultará aún más necesario cuando concurran una sanción disciplinaria y otra sanción administrativa general, dada la dispersión normativa del Derecho Administrativo Sancionador, que puede dificultar aún más la identificación del bien jurídico protegido ${ }^{92}$.

Junto a todo lo anterior, el Tribunal Constitución ha añadido a la prohibición del doble castigo varias reglas a las que se ha referido como vertiente procedimental del non bis in idem (material) ${ }^{93}$ y que pretenden resolver los conflictos que puede generar la existencia de hechos que sean constitutivos, al mismo tiempo, de delitos penales e infracciones administrativas: a) los Jueces y Tribunales del orden jurisdiccional penal tienen competencia exclusiva en caso de concurso de infracciones penales y administrativas, en consecuencia; b) la Administración no puede tramitar el procedimiento sancionador cuando se esté siguiendo un proceso penal por los mismos hechos y debe inhibirse si detecta que los hechos que está enjuiciando pueden ser constitutivos de delito; por último, c) la Administración debe respetar la declaración de hechos probados de la sentencia penal cuando, a pesar de ser hechos idénticos, esta pueda sancionar por tratarse de fundamentos diferentes ${ }^{94}$.

\subsection{El contenido de las sanciones penales y administrativas en materia discipli- naria: su relación con el puesto de trabajo}

El castigo por antonomasia en el Derecho Penal es la pena privativa de libertad (CPen, 1995, art. 32). En el caso del Derecho Administrativo Sancionador, sin embargo, existe una prohibición constitucional a la Administración civil ${ }^{95}$ de «imponer sanciones que, directa o subsidiariamente, impliquen privación de libertad» (CE, 1978, art. 25.3). Junto a la privación de libertad, la otra sanción más habitual del orden penal y la paradigmática del orden administrativo sancionador es la multa.

Sin embargo, en el régimen jurídico de la responsabilidad disciplinaria de los empleados públicos, estas sanciones quedan desplazadas por aquellas que afectan a la condición de empleado público. Así, los delitos tipificados en los Títulos XIX y XX CPen llevan aparejados, en su inmensa mayoría, la pena de inhabilitación por tiempo determinado para empleo público, sin perjuicio de que en algunos tipos penales se impongan la pena de prisión o de multa. Además, se prevé como pena accesoria la inhabilitación de empleo público para los delitos que no contemplen expresamente esta pena (CPen, 1995, arts. 54 y siguientes).

91. Así ocurrió, por ejemplo, en el caso de la pena por delito de cohecho y la sanción disciplinaria por falta disciplinaria muy grave consistente en «cualquier conducta constitutiva de delito doloso» que le impusieron a un policía nacional. En este caso, el Tribunal Supremo entendió que «tanto el delito castigado como la infracción administrativa vulneran el mismo interés jurídicamente protegido: el correcto funcionamiento de la Administración», por lo que la imposición de ambas sanciones conculcaría el principio non bis in idem (Tribunal Supremo, sentencia de 12 de junio de 1998).

Caso distinto, de conformidad con lo dicho, sería la comisión de un delito especial impropio, como el delito de detención ilegal cometido por funcionario público (CPen, 1995, art. 167), que tiene su delito común equivalente en el artículo $163 \mathrm{CPen}$. El bien jurídico protegido en este caso es la libertad de la víctima y no el correcto funcionamiento de la Administración, por lo que cabría la doble sanción penal y disciplinaria.

92. Por ejemplo, un policía que estando de servicio perturbara el desarrollo de una manifestación lícita en la vía pública podría incurrir en una infracción administrativa general, prevista en la Ley Orgánica 4/2005, de Protección de la Seguridad Ciudadana [artículo 36.8 «Son infracciones graves (...) 8. La perturbación del desarrollo de una reunión o manifestación lícita»] y, al mismo tiempo, podría incurrir en la falta disciplinaria muy grave consistente en «la obstaculización al ejercicio de las libertades públicas» [TREBEP, 2015, art. 95.2.k]). Aunque a primera vista se pudiese pensar que estamos ante infracciones idénticas, un análisis de ambos preceptos en el contexto normativo revela que, mientras en la infracción administrativa general se protege el libre ejercicio del derecho a manifestarse (CE, 1978, art. 21 CE), en la infracción disciplinaria el bien jurídico principal es el especial respeto a la Constitución y al resto del ordenamiento jurídico que todo empleado público debe profesar.

93. Sobre lo desacertado de esta expresión, véase a Alarcón Sotomayor, (2010, pp. 397-340).

94. Estas dos últimas reglas vienen expresamente recogidas en el artículo 94.3 TREBEP.

95. Nótese que el propio artículo 25.3 CE se refiere expresamente a la Administración «civil», por lo que queda excluida de esta prohibición la Administración militar, que podrá imponer sanciones administrativas consistentes en la privación de libertad. Así se puede ver en la LORDFAS (artículos 11 a 16). 
En el orden administrativo sancionador, el desplazamiento de la característica sanción de multa es aún más acentuado, hasta el punto de que esta ni siquiera se enumera entre las posibles sanciones que cabe imponer a los empleados públicos españoles ${ }^{96}$. Ello se debe a que, por oposición a la responsabilidad sancionadora general, «las sanciones disciplinarias se caracterizan por afectar a alguno de los derechos que corresponden a los empleados públicos como parte de su relación laboral con la Administración» (Bueno Armijo, 2018a, pp. 278 y siguientes), lo que deriva, una vez más, de la relación especial de sujeción que une a los empleados públicos y a la Administración y que aporta el marco conceptual de todo el derecho disciplinario. Así, se pueden encontrar entre las sanciones establecidas por el TREBEP el traslado forzoso, la suspensión de empleo y sueldo por un tiempo máximo de 6 años, la separación del servicio de los funcionarios o, su análogo, el despido disciplinario del personal labora ${ }^{97}$.

\subsection{La extinción de la responsabilidad penal y administrativa. En especial, la ex- tinción de la responsabilidad disciplinaria}

Con carácter general, la responsabilidad sancionadora, tanto penal como administrativa, se extingue por el cumplimiento de la sanción -penal o administrativa-; la muerte del sancionado (en nuestro caso, el empleado público); la prescripción del delito, de la infracción, de la pena o de la sanción, según los casos; el indulto y la amnistía (CPen, 1995, arts. 130 y siguientes; TREBEP, 2015, art. 97; y RRD, 1986, art. 19.1).

A estas causas hay que añadir, en el caso de la responsabilidad sancionadora disciplinaria, la pérdida de la condición de funcionario (RRD, 1986, art. 11.2, a contrario) ya que esta situación «supone la extinción de la relación de sujeción especial que une al empleado público con la Administración y, consecuentemente, supone el fin de su sometimiento a su especial régimen disciplinario» (Bueno Armijo, 2018a, pp. $282)^{98}$. Sin embargo, esta circunstancia «no libera de la responsabilidad civil o penal contraída por faltas cometidas durante el tiempo en que se ostentó aquella» (RRD, 1986, art. 11.2). Es decir, la pérdida de la condición de empleado público extinguirá la responsabilidad sancionadora disciplinaria, pero no la responsabilidad penal ni la responsabilidad patrimonial. No obstante, a pesar de esta previsión normativa, y por cuanto afecta a responsabilidad penal, lo cierto es que la pérdida de condición de empleado público (por ejemplo, por jubilación) también tendrá, en algunas ocasiones, el efecto de extinguir la responsabilidad penal, dado que las penas previstas para algunos de los delitos cometidos por empleados públicos, como ya advertimos, se vinculan a la relación jurídica especial que une al empleado público y a la Administración, relación jurídica que se extingue, justamente, con la pérdida de la condición de empleado público.

\section{La responsabilidad patrimonial del empleado público}

Una vez estudiadas las responsabilidades penal y disciplinaria del empleado público, es necesario completar el cuadro de la responsabilidad del empleado público con el estudio, aunque sea de forma breve, de su responsabilidad patrimonial frente a la Administración. Esta responsabilidad patrimonial del empleado público frente a la Administración no tiene su origen en el ejercicio del ius puniendi del Estado. Por el

96. Por oposición, la sanción de multa sí está prevista en el ordenamiento jurídico colombiano entre los posibles castigos que pueden recaer sobre los servidores públicos: artículo 44.4 del Código Disciplinario Único - Ley 734 de 2002 y artículos 48.6 y 48.710 del Código General Disciplinario - Ley 1952 de 2019.

97. Debe recordarse, además, que, al tratarse de una ley de mínimos, el TREBEP permite añadir cualquier otra sanción que se establezca por ley.

98. Existe aquí una nueva discrepancia, tal vez más aparente que real, entre el ordenamiento jurídico español y el ordenamiento jurídico colombiano. De conformidad con el artículo 25 del Código Disciplinario Único - Ley 734 de 2002, «Son destinatarios de la ley disciplinaria los servidores públicos, aunque se encuentren retirados del servicio ( )". Debe advertirse sin embargo, que el concepto de uservidores públicos» empleado por el Código Disciplinario

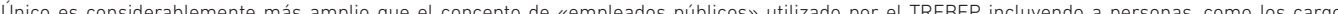
políticos electos, que difícilmente pueden ser considerados empleados de la Administración ni entenderse incluidos en una relación de sujeción especial. 
contrario, su origen y los principios en los que se inspira proceden de la responsabilidad extracontractual o aquiliana del Derecho Civil ${ }^{99}$.

Una de las consecuencias de esta diferencia en su naturaleza es que en ningún caso se conculca el principio non bis in idem si concurren la responsabilidad penal o disciplinaria junto con la responsabilidad patrimonial, en tanto que esta no consiste en un castigo al empleado público, sino en la reparación del daño causado, directa o indirectamente, a la Administración.

No obstante, la naturaleza civil de la responsabilidad patrimonial del empleado público frente a la Administración, y el hecho de que esta se inspire en principios eminentemente civiles, no obstan para que tenga una regulación completa en normas de Derecho Administrativo. En efecto, estando presente la Administración, se hace necesario adaptar y acomodar aquellos principios civiles al Derecho Administrativo y a las especiales características de la Administración pública (Véase Rebollo Puig, 2003, in totum; 2004, pp. 219-220; 2017, pp. 32-40; y García de Enterría y Fernández, 2015a, pp. 63-64).

Una de las consecuencias más relevantes, aunque no la única, de esta adaptación de la responsabilidad civil a las exigencias del Derecho Administrativo es la sustanciación de la responsabilidad del empleado público a través de un procedimiento administrativo (LRJSP, 2015, art. 36.4), resuelto por la propia Administración lesionada. Así pues, la Administración no necesita acudir, como si fuera un particular, a los Tribunales civiles para que estos declaren la responsabilidad patrimonial de su empleado público, sino que es ella misma la que instruye un procedimiento que determina dicha responsabilidad ${ }^{100}$.

Según queda dicho, pues, esta responsabilidad, de naturaleza civil, consiste en la obligación del empleado público de indemnizar los daños que haya causado en el patrimonio de la Administración en la que se integra. Estos daños pueden tener, de manera simplificada, dos orígenes. Por un lado, el daño puede consistir en una lesión directa en los bienes o derechos de la Administración donde desempeña el empleado sus funciones. Y, por otro lado, el daño también puede traer causa de la indemnización a la que la Administración ha tenido que hacer frente por la lesión en los bienes o derechos de un administrado, por culpa del empleado público. Para una mejor exposición, comenzaremos con el tipo de responsabilidad que presenta unas mayores peculiaridades: la responsabilidad por los daños causados a los ciudadanos por parte del empleado público.

\section{Daños ocasionados a los ciudadanos. la responsabilidad patri- monial indirecta del empleado público y la acción de regreso}

El ordenamiento jurídico español establece la responsabilidad directa de la Administración frente a los ciudadanos por los daños causados por sus empleados en el ejercicio de sus funciones ${ }^{101}$. Así lo consagra el artículo 106.2 CE:

«los particulares, en los términos establecidos por la ley, tendrán derecho a ser indemnizados por toda lesión que sufran en cualquiera de sus bienes y

99. Sobre la evolución histórica que ha experimentado la responsabilidad patrimonial frente a la Administración en el ordenamiento jurídico español, véase Fortes González (2014, pp. 37-102).

100. Como indica García Álvarez (2013, p. 615), estamos ante un supuesto del ejercicio de la potestad de autotutela de la Administración pública; autotutela que, en materia de responsabilidad civil, solo reside en este especial sujeto de derecho.

101. Su fin no es otro que el de garantizar la reparación, cuando así correspondiese, de los particulares ante la posible insolvencia del empleado público (Menéndez Sebastián, 2013, pp. 46-47). 
derechos, salvo en los casos de fuerza mayor, siempre que la lesión sea consecuencia del funcionamiento de los servicios públicos» ${ }^{102}$.

Sobre esta base, el legislador ha optado por excluir la posibilidad de que los ciudadanos puedan dirigirse directamente frente al empleado público que causó el daño (LRJSP, 2015, art. 36.1)103, salvo en el supuesto de responsabilidad civil derivada de delito, al que nos referiremos luego.

Ello, no obstante, no supone la irresponsabilidad patrimonial del empleado público. Al contrario, el artículo 36.2 LRJSP crea la llamada «acción de regreso» al disponer que «la Administración correspondiente, cuando hubiere indemnizado a los lesionados, exigirá de oficio en vía administrativa de sus autoridades y demás personal a su servicio la responsabilidad en que hubieran incurrido por dolo o culpa o negligencia graves, previa instrucción del correspondiente procedimiento» ${ }^{104}$.

De todo ello se debe destacar el especial grado de culpa requerido para que el empleado público incurra en responsabilidad patrimonial. Se trata de un rasgo que caracteriza a esta responsabilidad tanto respecto a la responsabilidad civil de un particular, como a la responsabilidad de carácter punitivo del empleado público ${ }^{105}$. Así, el artículo 36.2 LRJSP establece que la Administración podrá repetir mediante la acción de regreso contra el empleado público únicamente cuando concurra dolo o culpa o negligencia graves. Esta exigencia, sin duda, se configura como una medida de protección para el empleado público, el cual, de exigirse únicamente culpa, se podría encontrar demasiado expuesto a incurrir en responsabilidad patrimonial, lo que podría promover la inactividad de los empleados por el temor a la eventual responsabilidad personal, yendo en detrimento de la eficacia del funcionamiento de la Administración (CE, 1978, art. 103.1) 106 $^{10}$

Finalmente, debe señalarse que, por excepción, existe un único supuesto en el que los ciudadanos pueden dirigirse directamente contra los empleados públicos para exigir su responsabilidad patrimonial: la responsabilidad civil derivada del delito cometido por el empleado público que haya causado un perjuicio al ciudadano.

En este caso, el ciudadano lesionado, además de poder dirigirse directamente contra la Administración, puede exigirle al empleado público la responsabilidad civil derivada del delito en el mismo proceso penal en el que se determine la posible responsabilidad penal de aquel (LRJSP, 2015, art. 37.1; y CPen, 1995, art. 109.1). En este supuesto, si el empleado público satisface la indemnización fijada por el Juez, no habrá lugar a la responsabilidad patrimonial de la Administración, sino que se habrá generado una simple responsabilidad civil ex delicto, común a todo ciudadano con independencia de que tenga o no condición de empleado público.

102. Se ha de advertir, como recoge en su estudio jurisprudencial Gil Ibáñez (1994, pp. 30 y siguientes), que la jurisprudencia es clara al afirmar que el término «servicio público» a estos efectos «viene a ser sinónimo de [toda] actividad administrativa» [Tribunal Supremo, sentencia de 4 de enero de 1991 , FJ 2]. En términos muy similares encontramos también el artículo $121 \mathrm{CE}$, que igualmente consagra la responsabilidad del Estado por «el error judicial o el funcionamiento anormal de la Administración de Justicia».

103. En el mismo sentido ha sido redactado el artículo 296.1 LOPJ respecto la responsabilidad derivada del error judicial y el funcionamiento anormal de la Administración de Justicia. Esta elección, por otra parte, de acuerdo con Fortes González (2014), no parece haber mermado las garantías del ciudadano «teniendo en cuenta la complejidad que el desenvolvimiento de los servicios públicos y la actividad jurídico-administrativa presenta en nuestros días» ( $\mathrm{p}$. 95). De hecho, para algunos autores, esta posibilidad podría resultar hasta contraproducente. De esta opinión es Alonso Colomer (1993, p. 133).

104. En estos mismos términos encontramos el artículo 296.2 LOPJ. Nótese que, atendiendo a los términos en que se expresan ambas normas, no se configura la acción de regreso como una potestad discrecional de la Administración, sino como una obligación de instruir el procedimiento de responsabilidad patrimonial contra el empleado público. En este sentido se pronuncian Barcelona Llop (2000, pp. 44-49) e igualmente lo advierten Vera Jurado, Ávila Rodríguez y Rebollo Puig (2018, p. 268).

105. Bien es sabido que en el Derecho Civil basta con la culpa leve para que se derive responsabilidad de un privado frente a otro y que, en no pocas ocasiones, se contempla, incluso, la responsabilidad objetiva. Por lo que respecta a la responsabilidad de carácter punitivo, ya hemos indicado en los epígrafes anteriores de este trabajo el bajo grado de culpa que en ciertas ocasiones se necesita para sancionar o condenar a un empleado público, bastando, con carácter general, la mera negligencia.

106. En esta línea se expresa Blanquer Criado (1997, p. 104). 
Sin embargo, aún en el caso de optar la víctima del delito por la reclamación por vía penal, puede derivarse responsabilidad patrimonial de la Administración y eventualmente del empleado público frente a aquella. La razón es que, aunque la Administración no sea responsable civil directa, sí lo es a título de responsable subsidiaria (CPen, 1995, art. 121) ${ }^{107}$, por lo que, de no responder el empleado público, deberá hacerlo por él la Administración, lo que volverá a generar una acción de regreso de la Administración contra su empleado. Volveríamos pues al esquema general que previamente descrito.

\section{Daños ocasionados a la Administración. La responsabilidad patrimonial directa del empleado público}

Según establece el artículo 36.3 LRJSP se exigirá la misma responsabilidad que en el caso anterior al empleado público que lesione bienes o derechos de la Administración en la que desempeña sus funciones, siempre que, también en este supuesto, concurra dolo o culpa o negligencia graves ${ }^{108}$.

En este caso, la responsabilidad patrimonial del empleado público frente a su Administración únicamente se producirá cuanto tenga su origen en un daño o lesión que haya producido en el ejercicio de sus funciones. En efecto, al igual que el resto de las responsabilidades del empleado público frente a su Administración, la responsabilidad patrimonial del empleado público tiene su fundamento en la finalidad de garantizar el correcto funcionamiento de la Administración (lo que incluye la indemnidad de su patrimonio) y en la relación especial de sujeción que vincula al empleado público con la Administración donde ejerce sus funciones.

De conformidad con este planteamiento, todo daño que ocasione el empleado público con total desconexión de sus funciones o de su condición de empleado público no originará una responsabilidad patrimonial exigible con base en el artículo 36.3 LRJSP, sino una responsabilidad civil común a la de cualquier otro ciudadano (Fortes González, 2014, p. 129; y Parada Vázquez, 1993, p. 448). Así pues, deberá exigírsele tal responsabilidad ante la jurisdicción civil, incluso si los daños son ocasionados directamente a la Administración. Es decir, la simple condición de empleado público no basta para justificar que la Administración pueda determinar por sí misma la responsabilidad civil o patrimonial de este. Es necesario, además, que los daños producidos estén relacionados con tal condición. A ello, debe sumarse, además, la concurrencia de dolo o culpa o negligencia graves en los mismos términos ya indicados para la acción de regreso.

\section{Conclusiones}

Para garantizar el buen funcionamiento de la Administración pública y del resto de poderes públicos es imprescindible un sistema de responsabilidad del empleado público que prevenga, reprenda y corrija aquellos comportamientos contrarios a sus principios más básicos: pleno sometimiento al ordenamiento jurídico, objetividad, eficacia y jerarquía (ex CE, 1978, arts. 9.3 y 103.1). E, igualmente, que exija la reparación de los daños que aquellas conductas hayan podido causar. En nuestro trabajo se han identificado y estudiado tres tipos de responsabilidad de los empleados públicos en España: penal, disciplinaria y patrimonial. Las dos primeras se han estudiado conjuntamente

107. De ahí que, si efectivamente la víctima exige la responsabilidad civil del empleado público en el proceso penal, «la pretensión deberá dirigirse simultáneamente contra la Administración o ente público presuntamente responsable civil subsidiario» (CPen, 1995, art. 121 in fine).

108. Así, por ejemplo, el caso de la STSJ de Extremadura 1136/2004. Según se expone en la sentencia, el empleado de un Ayuntamiento había recibido un teléfono móvil (por razones de trabajo) y recibido otro en sustitución sin que fuera devuelto el primero. Siguiendo, pues, el primer móvil en posesión del empleado, todos los miembros de la familia del empleado hicieron uso habitual de este, sin que el empleado público tomase ninguna medida al respecto siendo consciente de dicho uso indebido. En vista de estos hechos, el Tribunal confirmó la declaración de responsabilidad patrimonial del empleado. Otros ejemplos de esta forma de responsabilidad patrimonial los encontramos en las STSJ de Madrid 642/2013; y STSJ de Castilla y León/Valladolid 759/2012. 
como manifestaciones del ius puniendi del Estado, mientras que la responsabilidad patrimonial se ha tratado de manera separada en tanto su naturaleza civil la distingue de las otras dos.

Nuestro estudio permite confirmar, en primer lugar, que no hay un concepto único de empleado público común a todo el ordenamiento jurídico español, sino que varía según cada tipo de responsabilidad. Así, en el régimen disciplinario se utiliza un concepto formal o estricto de empleado público como aquel que trabaja al servicio de una Administración pública y reúne los requisitos marcados por el TREBEP. En cambio, aunque con diferente alcance, tanto en la responsabilidad penal como en la patrimonial, se hace uso de un concepto material o funcional, donde el dato relevante es el ejercicio de funciones públicas.

Del mismo modo, nuestro trabajo deja patente las distintas peculiaridades del régimen de responsabilidad del empleado público frente al régimen de responsabilidad al que se somete cualquier otro ciudadano. Ello debido a la posición que ocupa dentro de la Administración y los principios de actuación que eso conlleva. De este modo, la cualidad de empleado público y los principios y deberes de este modulan la responsabilidad de carácter punitivo y la responsabilidad patrimonial, aunque en sentidos opuestos.

En efecto, en la responsabilidad penal y en la disciplinaria, la cualidad de empleado público y, en concreto, el especial deber de saber, justifican ciertas relajaciones en algunas garantías frente al ius puniendi del Estado, como los principios de tipicidad, reserva de ley y culpabilidad, cuyo respeto es exigido con mayor rigor en otros ámbitos sectoriales, en los términos que hemos indicado en las páginas precedentes. No obstante, no se observan diferencias en la aplicación de otros principios, como el principio de irretroactividad de la norma sancionadora desfavorable, el principio de antijuridicidad o el principio non bis in idem.

Por su parte, en la responsabilidad patrimonial se aprecia una mayor protección del empleado público ante una eventual producción de un daño a la Administración o a un particular. La finalidad principal de esta mayor protección es no fomentar la inactividad de los empleados públicos -y, por ende, de los poderes públicos-, por el miedo a incurrir en responsabilidad. Esto iría en contra del principio de eficacia de la Administración. De acuerdo con ello, el ordenamiento jurídico español no permite que los particulares se dirijan directamente contra el empleado público (salvo en el caso de comisión de delito). La Administración será la que asuma la indemnización correspondiente. Y, solo en el caso de que haya concurrido dolo o culpa grave por parte del empleado público, podrá la Administración repetir contra él mediante la llamada acción de regreso. Asimismo, se requerirá también dolo o culpa grave en el caso de que el empleado haya lesionado directamente los bienes o derechos de la Administración para que se genere la responsabilidad patrimonial de aquel y pueda ser exigida, directamente y sin necesidad de acudir a los Tribunales, por esta.

\section{Referencias}

Alarcón Sotomayor, L. (2010). Concurso de infracciones, concurso de normas punitivas: non bis in idem. En: M. Rebollo Puig, M. Izquierdo Carrasco, L. Alarcón Sotomayor y A. Bueno Armijo. Derecho Administrativo Sancionador. Valladolid: Lex Nova. 
Alarcón Sotomayor, L. (2014). Los confines de las sanciones: en busca de la frontera entre Derecho Penal y Derecho Administrativo Sancionador. Revista de Administración Pública (195).

Alonso Colomer, F. (1993). La responsabilidad patrimonial de los empleados públicos en el marco estatutario. Revista Gallega de la Administración Pública (RGAP) (5).

Baca Oneto, V. S. (2019). La culpabilidad en el Derecho Administrativo Sancionador, con especial mirada al caso peruano. Revista Digital de Derecho Administrativo (21).

Barcelona Llop, J. (2000). La acción de regreso en la Ley de Régimen Jurídico de las Administraciones Públicas y del Procedimiento Administrativo Común. Revista Española de Derecho Administrativo (REDA) (105).

Blanquer Criado, D. V. (1997). La responsabilidad patrimonial de las Administraciones públicas. Madrid: Instituto Nacional de Administración Pública (INAP).

Bueno Armijo, A. (2010a). El principio de legalidad sancionadora (I): la reserva de ley. En: M. Rebollo Puig, M. Izquierdo Carrasco, L. Alarcón Sotomayor y A. Bueno Armijo. Derecho Administrativo Sancionador. Valladolid: Lex Nova.

Bueno Armijo, A. (2010b). El principio de legalidad sancionadora (II): el principio de tipicidad. En: M. Rebollo Puig, M. Izquierdo Carrasco, L. Alarcón Sotomayor y A. Bueno Armijo. Derecho Administrativo Sancionador. Valladolid: Lex Nova.

Bueno Armijo, A. (2010c). El principio de legalidad sancionadora (III): la irretroactividad de las disposiciones sancionadoras no favorables. En: M. Rebollo Puig, M. Izquierdo Carrasco, L. Alarcón Sotomayor y A. Bueno Armijo. Derecho Administrativo Sancionador. Valladolid: Lex Nova.

Bueno Armijo, A. (2010d). La antijuridicidad como elemento de la infracción administrativa. En: M. Rebollo Puig, M. Izquierdo Carrasco, L. Alarcón Sotomayor y A. Bueno Armijo. Derecho Administrativo Sancionador. Valladolid: Lex Nova.

Bueno Armijo, A. (2018a). La responsabilidad de los empleados públicos. En: M. Rebollo Puig y Diego J. Vera Jurado (dirs.). Derecho Administrativo, Tomo IV. Madrid: Tecnos.

Bueno Armijo, A. (2018b). Non bis in idem en el Derecho Europeo: garantía sustancial y procesal. En: A. Montaña Plata y J. I. Rincón Córdoba (eds.). El poder sancionador de la Administración pública: discusión, expansión y construcción. Bogotá: Universidad Externado.

Cámara del Portillo, D. (2008). Régimen disciplinario de los empleados públicos. La nueva regulación de la Ley 7/2007, de 12 de abril, del Estatuto Básico del Empleado. Madrid: Marcial Pons.

Castillo Blanco, F. A. (1992). Función pública y poder disciplinario del Estado. Madrid: Civitas y $\mathrm{CEMCl}$.

Cosculluela Montaner, L. (2016). Manual de Derecho Administrativo. Cizur Menor (Navarra): Civitas. 27. ${ }^{a}$ edición. 
De la Torre Martínez, L, Izquierdo Carrasco, M. y López Benítez, M. (2018). Deberes de los empleados públicos. En especial, el régimen de incompatibilidades. En: M. Rebollo Puig y D. J. Vera Jurado (dirs.). Derecho Administrativo, Tomo IV. Madrid: Tecnos.

Díaz y Díaz, M. C. (2011). El empleado público ante el procedimiento administrativo: deberes y obligaciones de buena administración. Las Rozas (Madrid): La Ley.

Echevarría, M. H. (2019). Delitos de los funcionarios públicos. Madrid: Dykinson.

Fernández Ramos, S. (2013). Los falsos empleados públicos: el personal eventual. Revista General de Derecho Administrativo (RGDA) (34).

Fortes González, A. I. (2014). La responsabilidad patrimonial de las autoridades y personal al servicio de las Administraciones Públicas. Madrid: Instituto Nacional de Administración Pública.

Gallardo Castillo, M. J. (2015). Régimen Disciplinario de los funcionarios públicos. Cizur Menor (Navarra): Aranzadi.

García-Álvarez, G. (2013). La responsabilidad patrimonial de autoridades y personal al servicio de las Administraciones públicas. En: T. Quintana López (dir.). La responsabilidad patrimonial de la Administración pública. Valencia: Tirant lo Blanch. 2. ${ }^{a}$ edición.

García de Enterría, E. y Fernández, T. R. (2015a). Curso de Derecho Administrativo. Tomo I. Cizur Menor (Navarra): Civitas, 17. ${ }^{\text {a edición. }}$

García de Enterría, E. y Fernández, T. R. (2015b). Curso de Derecho Administrativo. Tomo II, Cizur Menor (Navarra): Civitas, 14. ${ }^{a}$ edición.

Gil Ibáñez, J. L. (1994). La responsabilidad patrimonial de los poderes públicos. Madrid: La Ley.

Gimeno Sendra, V. (2003). Cuestiones devolutivas y non bis in idem en el proceso penal. Revista jurídica española de doctrina, jurisprudencia y bibliografía (3).

Gómez Pavajeau, C. A. (2011). Dogmática del Derecho Disciplinario. Bogotá: Universidad de Externado de Colombia. 5. ${ }^{a}$ edición.

Gómez Tomillo, M. y Sanz Rubiales, I. (2017). Derecho Administrativo Sancionador. Parte General. Cizur Menor (Navarra): Aranzadi, 4. ${ }^{a}$ edición.

Hernández Suárez-Llanos, F. J. (2010). A vueltas con la obediencia debida: ¿mandatos antijurídicos obligatorios? Revista Jurídica de la Universidad Autónoma de Madrid (22).

Izquierdo Carrasco, M. (2010). La culpabilidad y los sujetos responsables. En: M. Rebollo Puig, M. Izquierdo Carrasco, L. Alarcón Sotomayor y A. Bueno Armijo. Derecho Administrativo Sancionador. Valladolid: Lex Nova.

López Benítez, M. (1994). Naturaleza y presupuestos constitucionales de las relaciones especiales de sujeción. Madrid: Civitas y Universidad de Córdoba. 
Marina Jalvo, B. (2015). El Régimen Disciplinario de los Empleados Públicos. Cizur Menor (Navarra): Aranzadi.

Mauri Majós, J. (2018). El acceso irregular a los empleados públicos: la erosión del principio de mérito. En: J. Ponce Solé (coord.). Empleo público, derecho a una buena administración e integridad. Valencia: Tirant lo Blanch.

Méndez Rodríguez, C. (1993). Los delitos de peligro y sus técnicas de tipificación. Madrid: Universidad Complutense de Madrid.

Menéndez Sebastián, E. M. a (2013). Principios de la responsabilidad extracontractual de la Administración pública (Artículos 139 y 131 LRJPAC). En: T. Quintana López. La Responsabilidad patrimonial de la Administración pública, Tomo I. Valencia: Tirant lo Blanch. 2. ${ }^{a}$ edición.

Mir Puigpelat, O. (2002). La responsabilidad patrimonial. Hacia un nuevo sistema. Madrid: Civitas.

Muñoz Conde, F. (2015). Derecho Penal. Parte Especial. Valencia: Tirant lo Blanch. 20. ${ }^{a}$ edición.

Nieto García, A. (1992). La jerarquía administrativa. Documentación Administrativa (229).

Nieto García, A. (2012). Derecho Administrativo Sancionador. Madrid: Tecnos. $5^{a}$ edición.

Parada Vázquez, R. (1993). Régimen Jurídico de las Administraciones públicas y Procedimiento Administrativo Común (Estudio, comentarios y texto de la Ley 30/1992, de 26 de noviembre). Madrid: Marcial Pons.

Parada Vázquez, R. y Fuentetaja Pastor, J. A. (2017). Derecho de la Función Pública. Cizur Menor (Navarra): Civitas.

Ponce solé, J. (2018). Empleo público, derecho a una buena administración e integridad. Valencia: Tirant lo Blanch.

Rebollo Puig, M. (2003). El Derecho Administrativo como derecho único de la Administración. Revista General de Derecho Administrativo (RGDA) (2). Madrid.

Rebollo Puig, M. (2004). Sobre la reforma del régimen de responsabilidad patrimonial de la Administración. En: F. Sáinz Moreno (dir.), Estudios para la reforma de la Administración Pública. Madrid: Instituto Nacional de Administración Pública.

Rebollo Puig, M. (2010a). Derecho Administrativo Sancionador y Derecho Penal. En: M. Rebollo Puig, M. Izquierdo Carrasco, L. Alarcón Sotomayor y A. Bueno Armijo. Derecho Administrativo Sancionador. Valladolid: Lex Nova.

Rebollo Puig, M. (2010b). En especial, el principio non bis in idem en sanciones disciplinarias. En: M. Rebollo Puig, M. Izquierdo Carrasco, L. Alarcón Sotomayor y A. Bueno Armijo. Derecho Administrativo Sancionador. Valladolid: Lex Nova. 
Rebollo Puig, M. (2017). Derecho Administrativo y Administración pública. En: M. Rebollo Puig y Diego J. Vera Jurado (dirs.). Derecho Administrativo, Tomo I. Madrid: Tecnos. 3. ${ }^{a}$ edición.

Rebollo Puig, M. e Izquierdo Carrasco, M. (2018). Derecho Administrativo Sancionador: caracteres generales y garantías materiales. En: M. Rebollo Puig y D. J. Vera Jurado (dirs.). Derecho Administrativo, Tomo II. Madrid: Tecnos. 3. a edición.

Rincón Córdoba, J. I. (2018). La potestad disciplinaria en el Derecho Administrativo. Buenos Aires: Editores IJ y Universidad de Piura.

Rodríguez-Arana Muñoz, X. (2013) El derecho a una buena administración para los ciudadanos: un modelo global de Administración. La Coruña: Netbiblio.

Sánchez Morón, M. (2018). Derecho de la Función Pública. Madrid: Tecnos. 11. a edición.

Santamaría Pastor, J. A. (2009). Principios de Derecho Administrativo general, Tomo I. Madrid: lustel. 2. ${ }^{a}$ edición.

Tomás Mallén, B. (2004). El derecho fundamental a una buena administración. Madrid: Instituto Nacional de Administración Pública (INAP).

Vera Jurado, D. J., Ávila Rodríguez, C. M. y Rebollo Puig, M. (2018). La responsabilidad patrimonial de la Administración pública. En: M. Rebollo Puig y Diego J. Vera Jurado (dirs.). Derecho Administrativo, Tomo II. Madrid: Tecnos. 3. a edición.

Zúñiga Morales, S. E. (2004). Cuando las normas penales en blanco vulneran el principio de legalidad. Revista de Derecho (8). Managua (Nicaragua): Universidad Centroamericana (UCA).

\section{Anexo jurisprudencial}

Tribunal Europeo de Derechos Humanos. Sentencia de 21 de febrero de 1984 (caso Öztürk c. RFA).

Tribunal Europeo de Derechos Humanos. Sentencia de 23 de octubre de 1995 (caso Gradinger c. Austria).

Tribunal Europeo de Derechos Humanos. Sentencia de 29 de mayo de 2001 (caso Franz Fischer c. Austria).

Tribunal Constitucional. Sentencia 83/1980, de 5 de noviembre.

Tribunal Constitucional. Sentencia 2/1981, de 30 de enero.

Tribunal Constitucional. Sentencia 8/1981, de 30 de marzo.

Tribunal Constitucional. Sentencia 18/1981, de 18 de junio.

Tribunal Constitucional. Sentencia 62/1982, de 15 de octubre.

Tribunal Constitucional. Sentencia 85/1983, de 25 de octubre. 
Tribunal Constitucional. Sentencia 2/ 1987, de 21 de enero.

Tribunal Constitucional. Sentencia 42/1987, de 5 de mayo.

Tribunal Constitucional. Sentencia 3/1988, de 21 de enero.

Tribunal Constitucional. Sentencia 101/1988, de 8 de junio.

Tribunal Constitucional. Sentencia 69/1989, de 20 de abril.

Tribunal Constitucional. Sentencia 76/1990, de 26 de abril.

Tribunal Constitucional. Sentencia 133/1990, de 15 de julio.

Tribunal Constitucional. Sentencia 150/1991, de 4 de julio.

Tribunal Constitucional. Sentencia 234/1991, de 10 de diciembre.

Tribunal Constitucional. Sentencia 246/1991, de 19 de diciembre.

Tribunal Constitucional. Sentencia 21/1993, de 18 de enero.

Tribunal Constitucional. Sentencia 120/1996, de 8 de julio.

Tribunal Constitucional. Sentencia 151/1997, de 29 de septiembre.

Tribunal Constitucional. Sentencia 132/2001, de 8 de junio.

Tribunal Constitucional. Sentencia 9/2006, de 16 de enero.

Tribunal Constitucional. Sentencia 283/2006, de 9 de octubre.

Tribunal Constitucional. Sentencia 116/2007, de 21 de mayo.

Tribunal Constitucional. Sentencia 162/2008, de 15 de diciembre.

Tribunal Constitucional. Sentencia 144/2011, de 26 de septiembre.

Tribunal Constitucional. Sentencia 13/2013, de 28 de enero.

Tribunal Supremo. Sentencia de 4 de enero de 1991 (rec. s/n).

Tribunal Supremo. Sentencia de 29 de enero de 1992 (rec. s/n)

Tribunal Supremo. Sentencia 910/1997, de 24 de junio (rec. 1944/1996).

Tribunal Supremo. Sentencia 692/1997, de 7 de noviembre (rec. 2596/1995).

Tribunal Supremo. Sentencia de 28 de abril de 1998 (rec. 6240/1990).

Tribunal Supremo. Sentencia de 12 de mayo de 1998 (rec. 388/1994). 
Tribunal Supremo. Sentencia de 19 de mayo de 1998 (rec. 584/1994).

Tribunal Supremo. Sentencia de 12 de junio de 1998 (rec. 5585/1995).

Tribunal Supremo. Sentencia de 14 de julio de 1998 (rec. 11759/1990).

Tribunal Supremo. Sentencia de 1 de febrero de 1999 (rec. 4839/1998).

Tribunal Supremo. Sentencia de 15 de febrero de 1999 (rec. 8848/1991).

Tribunal Supremo. Sentencia de 20 de diciembre de 1999 (rec. 429/1997).

Tribunal Supremo. Sentencia de 3 de abril de 2000 (rec. 44/1999).

Tribunal Supremo. Sentencia de 30 de mayo de 2000 (rec. 513/1996).

Tribunal Supremo. Sentencia de 22 de julio de 2000 (rec. 2707/1993).

Tribunal Supremo. Sentencia de 16 de marzo de 2001 (rec. 8018/1996).

Tribunal Supremo. Sentencia de 30 de marzo 2001 (rec. 9347/1996).

Tribunal Supremo. Sentencia de 26 de junio de 2001 (rec. 120/1999).

Tribunal Supremo. Sentencia 161/2002, de 4 de febrero (rec. 256/2000).

Tribunal Supremo. Sentencia de 17 de abril de 2002 (rec. 171/2000).

Tribunal Supremo. Sentencia 1053/2002, de 5 de junio (rec. 1214/2000).

Tribunal Supremo. Sentencia de 5 de junio de 2002 (rec. 10/2001).

Tribunal Supremo. Sentencia de 11 de abril de 2003 (rec. 470/2001).

Tribunal Supremo. Sentencia 1590/2003, de 22 de abril (rec. 2074/2001).

Tribunal Supremo. Sentencia de 16 de marzo de 2004 (rec. 10700/1998).

Tribunal Supremo. Sentencia 406/2004, de 31 de marzo (rec. 288/2003).

Tribunal Supremo. Sentencia de 4 de junio de 2004 (rec. 137/2003).

Tribunal Supremo. Sentencia 725/2004, de 11 de junio (rec. 471/2003).

Tribunal Supremo. Sentencia de 9 de diciembre de 2005 (rec. 253/2003).

Tribunal Supremo. Sentencia 211/2006, de 2 de marzo (rec. 1902/2004).

Tribunal Supremo. Sentencia de 25 de septiembre de 2006 (rec. 157/2003).

Tribunal Supremo. Sentencia 1076/2006, de 27 de octubre (rec. 1293/2005). 
Tribunal Supremo. Sentencia de 6 de marzo de 2006 (rec. 93/2004).

Tribunal Supremo. Sentencia 636/2006, de 8 de junio (rec. 1312/2085).

Tribunal Supremo. Sentencia de 10 de octubre de 2006 (rec. 16/2006).

Tribunal Supremo. Sentencia 300/2012, de 3 de mayo (rec. 1445/2011).

Tribunal Supremo. Sentencia 2614/2016, de 14 de diciembre (rec. 264/2015).

Tribunal Supremo. Sentencia 548/2017, de 30 de marzo (rec. 3300/2015).

Tribunal Supremo. Sentencia 32/2018, de 22 de marzo (rec. 117/2017).

Tribunal Supremo. Sentencia 257/2019, de 22 de mayo (rec. 735/2018).

Tribunal Supremo. Sentencia 163/2019, de 26 de marzo (rec. 2263/2017).

Tribunal Supremo. Sentencia 763/2019, de 3 de junio (rec. 245/2018).

Audiencia Nacional. Sentencia de 14 de diciembre de 2006 (rec. 48/2005).

Audiencia Nacional. Sentencia de 11 de febrero de 2013 (rec. 59/2012).

Tribunal Superior de Justicia de Castilla y León 266/2008. Sentencia de 23 de junio (rec. 545/2006).

Tribunal Superior de Justicia de Castilla y León 759/2012. Sentencia de 20 de abril, (rec. 1263/2008).

Tribunal Superior de Justicia de Extremadura 1136/2004. Sentencia de 20 de julio (rec. 1064/2002).

Tribunal Superior de Justicia de Madrid 818/2002. Sentencia de 16 de julio (rec. 1284/1997).

Tribunal Superior de Justicia de Madrid 642/2013. Sentencia de 30 de abril (rec. 3276/2012).

Juzgado de lo Contencioso-administrativo de Sevilla. Sentencia de 28 de mayo de 2015 (rec. 516/2012).

Corte constitucional de Colombia. Sentencia C-195, de 20 de mayo de 1993.

Corte constitucional de Colombia. Sentencia C-214, de 28 de abril de 1994.

Corte constitucional de Colombia. Sentencia C-280, de 25 de junio de 1996.

Corte constitucional de Colombia. Sentencia C-306, de 11 de julio de 1996.

Corte constitucional de Colombia. Sentencia C-597, de 6 de noviembre de 1996. 
Corte constitucional de Colombia. Sentencia C-310, de 25 de junio de 1997.

Corte constitucional de Colombia. Sentencia C-554, de 30 de mayo de 2001.

Corte constitucional de Colombia. Sentencia C-827, de 8 de agosto de 2001.

Corte constitucional de Colombia. Sentencia C-406, de 4 de mayo de 2004.

Corte constitucional de Colombia. Sentencia C-948, de 6 de noviembre de 2002.

Corte constitucional de Colombia. Sentencia C-818, de 9 de agosto de 2005.

Corte constitucional de Colombia. Sentencia T-1034, de 5 de diciembre de 2006.

Corte constitucional de Colombia. Sentencia T-068, de 4 de febrero de 2009. 